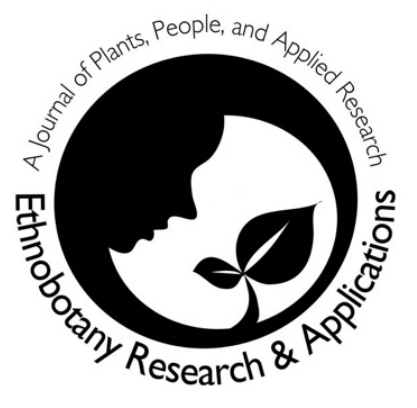

\title{
Effect and impact of indigenous knowledge on local biodiversity and social resilience in Pamir region of Tajik and Afghan Badakhshan
}

\section{Aziz Ali}

Correspondence

Aziz Ali

Mountain Societies Research Institute (MSRI); University of Central Asia (UCA), Khorog Campus, Tajikistan

*Corresponding Author: azizali.khan@ucentralasia.org

Ethnobotany Research \& Applications 22:03 (2021)

\section{Research}

\begin{abstract}
Background: Pamir mountain communities hold vast knowledge of plants important for health and food security. However, little research is conducted on this topic.

Methods: This study explores the contribution of indigenous knowledge of mountain dwellers and assesses how it contributes to biodiversity conservation, adaptation, and social/community resilience in the Pamir region of Tajik and Afghan Badakhshans. Secondary sources on medicinal plants were reviewed and then, 280 individual interviews and three focus group discussions were conducted in four border districts of Afghan and Tajik Badakhshans respectively during 2017-18. Using a multi-stage random sampling technique, first, research districts, then, villages/valleys and last, households were selected, limiting the sample size to $20 \%$ in all stages due to vast study area.
\end{abstract}

Results: Pamir mountain communities depend on natural environment for their livelihood needs, particularly using plants for remedies and food. Respondents used 128 plant species belonging to 63 families and 81 genera. The most marketable medicinal plants grew far away from settlements indicating pressure and over-harvesting of plants. Local communities' knowledge of plant usage for food, therapeutics and traditional rituals is key to community/social resilience and conservation of plants within farmlands and natural environment.

Conclusion: Medicinal plants decreased substantially in their natural habitats over the past 15 years, which may negatively impact people's traditional health systems and food security. However, knowledge about biodiversity and importance of plants has increased. Participatory conservation strategies for medicinal plants and associated indigenous knowledge is necessary for the benefits of present and future generations of Pamir mountain communities.

Key words: Indigenous knowledge, conservation, biodiversity, social resilience, medicinal plants, food security, Pamir, Badakhshan, Afghanistan, Tajikistan 


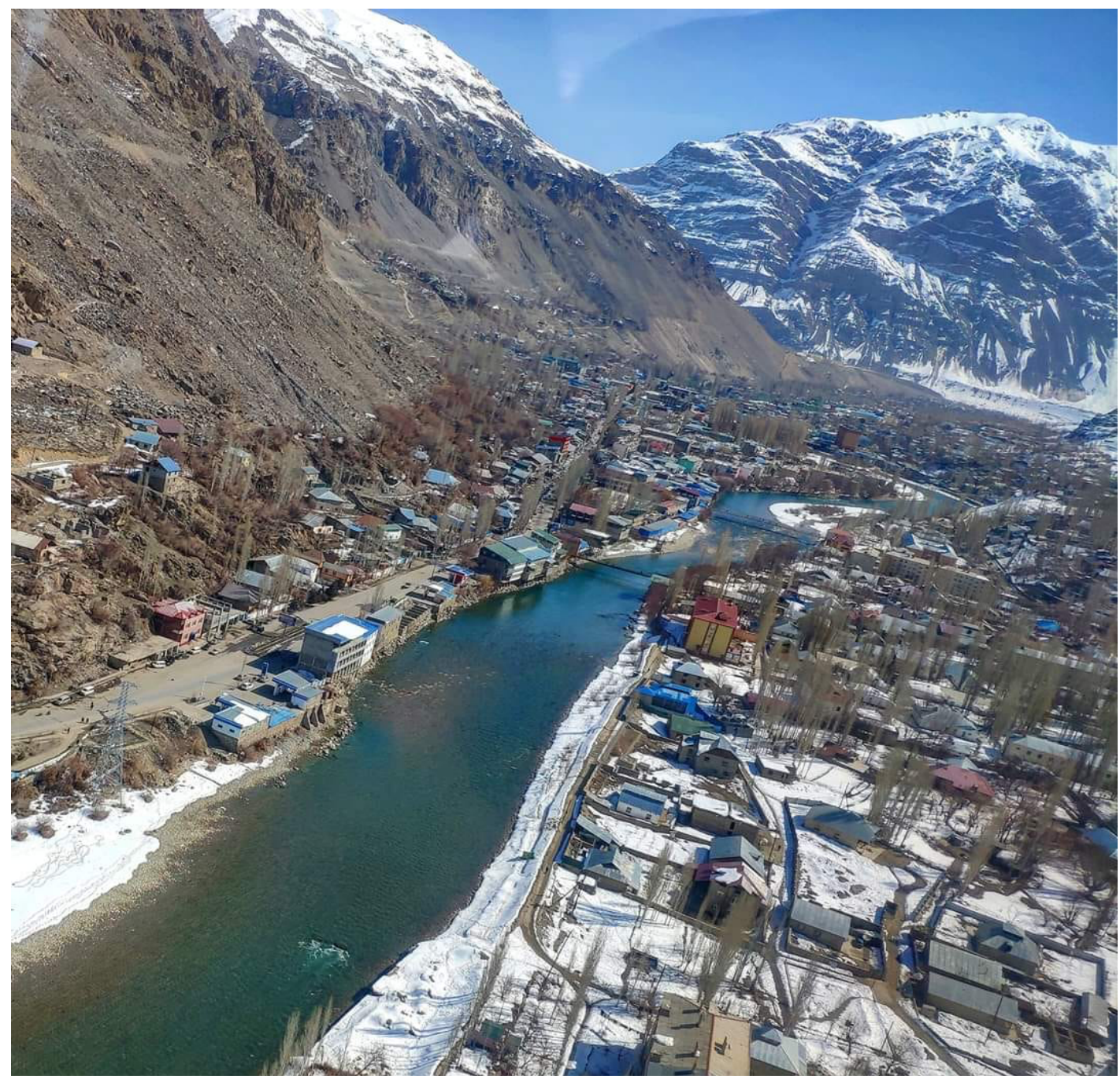

Pamir mountain community Khorog town, Tadjikistan (Photo Anonymous)

\section{Background}

Badakhshan, geographically located at the junctions of Asia's mightiest mountain ranges - the Himalaya, Karakoram, Hindu Kush, and Tian Shan - harbors rich floral and faunal diversity. The affinities with different mountain ranges and high vertical relief of Pamir Badakhshan offer diverse habitats to a large variety of species, thus supporting rich and unique biodiversity.

The indigenous people of the Pamir mountains hold vast knowledge about their environment and natural resources, based on their proximity to nature and interacting with diverse and complex ecosystems for livelihoods over the centuries. They have traditionally been engaged in conservation of species of significance for food security and health systems in many ways, including domesticating species from the natural environment, storing seeds/propagules, budding, grafting, and exchange of seeds among neighbors and relatives within and outside the villages besides conservation of the species in mountains, forests and grazing lands/pastures.

The Pamir region contains a variety of ecosystems including temperate grasslands, savannas, shrublands, deserts and open woodlands, and much of the area is mountainous and at high altitude. Badakhshan's extensive mountain areas contain an extensive array of high value, low volume products like non-timber forest products (NTFPs), including medicinal and aromatic plants (MAPs), and honeybee products. The region is suitable for cultivating temperate and off-season crops (Kruse, 2015, p. 12). Some species, such as those found within the Wakhan Corridor, have adapted to a "dry high-altitude steppe-environment" and might be of particular interest to a MAPs promotion project. The region is home to a multi-ethnic population that faces extreme poverty and is closely connected to the land. Amidst extreme climatic and geographic conditions, high quality medicinal and aromatic plant species have thrived and adapted, and the local population possesses valuable indigenous knowledge about how local plants are used as medicine and to promote health. Unfortunately, the primary producers and collectors of wild 
MAPs receive a relatively small share of returns because of insufficient knowledge of market chains, lack of processing facilities, inadequate quality control, and other factors (Kruse, 2015)

Indigenous peoples with a historical continuity of resource use practices often possess a broad knowledge base of the behavior of complex ecological systems in their own localities (Madhav et al. 1993). This knowledge has accumulated through a long series of observations transmitted from generation to generation. They are aware that biological diversity is a crucial factor in generating the ecological services and natural resources on which they depend. Their practices for the conservation of biodiversity were grounded in a series of 'rules of thumb' that were determined through a trial-and-error process over a long period of time. This implies that their knowledge base is sometimes indefinite, and their implementation involves an intimate relationship with their belief system. Such knowledge is different from modern science that is based on the knowledge system of the Western World. It is vital, however, that the value of the knowledge-practice-belief complex of indigenous peoples relating to conservation of biodiversity is fully recognized if ecosystems and biodiversity are to be managed sustainably (Madhav et al. 1993).

Indigenous knowledge of medicinal plants in the Pamirs is fundamentally dependent on its use. Knowledge of medicinal plants and ideal growing conditions is not only embedded in peoples' minds but in their relations within their habitat. This knowledge is critical to the adaptation and resilience of these communities under conditions of socio-cultural and environmental change. As medicinal plant use is context specific, there may be differences in use between people with different ecological professions, such as pastoralists and agriculturalists. Furthermore, there is opportunity to examine differentiated medicinal plant uses by ethnicities, elevation, and valleys of the Pamir Mountains of Afghanistan and Tajikistan (Kassam et al. 2010).

Most of the available literature focuses on MAPs in Wakhan district of Badakhshan. Some study reveals that In Wakhan, the Afghan Kyrgyz pastoralist population collects a range of wild plants from areas not far from their seasonal settlements. Kishem, Jurm and Shughnan districts provide good environment and high potential for mulberries (Kruse, 2015). As many as 15\% of the Kyrgyz use plants that are collected in Wakhan, all of which are truly wild. They are not familiar with any of the anthropogenic plants in and around Wakhi villages and field (Soelberg, et al, 2016).

Studies of medicinal plants in Afghanistan date back to 1886, with another assessment made in 1965- 67 (Wafiq, n.d.). Field missions undertaken by Jens Soelberg, et al (2016) involved collecting extensive species specimens. Soelberg's reports on Comparative Ethnobotany (2016), Useful Plants of the Wakhan and Pamir (2016), and the Wakhan and Pamir Expedition Report (2011) are invaluable guides to socio-cultural and historical background of the region and perhaps offer the most comprehensive listing of plant species in Wakhan and their uses available in English. Soelberg's reports on Comparative Ethnobotany (2016) present a study of plant names and uses, comparisons of plant name etymology, origins of plant resources, intra- and intercultural exchanges and relations, and relative availability of known and used plants. Researchers have identified as many as 3000 species of medicinal value in the region. According to Wafiq, 650 medicinal plant species can be grown commercially, and the Afghan Ministry of Commerce has been assisting in finding markets for between 46 species (Wafiq, n.d) and 65 species (ICARDA 2006). Kassam et al's artile (2010) is the result of over a decade of fieldwork by the first and second authors who lived and researched at a range of elevations in valleys throughout Gorno Badakhshan Autonomous Oblast (GBAO) of Tajikistan and the Badakhshan Province of Afghanistan. It presents plant uses in the context of mountain communities and identifies over 58 cultivated and non-cultivated plants from the region. More than 310 distinct uses within 63 categories of treatment and prevention are discussed. Kassam et al refer to a Wildlife Conservation Society range-land assessment that investigated 150 botanical specimens from the Wakhan Corridor in 2006, although that report has not been located for review.

Medicinal and aromatic plants (MAPs) are botanical raw materials that are primarily used for therapeutic, aromatic and/or culinary purposes as components of medicinal products, health foods and other natural health products. Plant based herbal medicines have been used for thousands of years in many parts of the world. The therapeutic use of herbal medicines is gaining considerable momentum in the world during the last decade. The World Health Organization (WHO) estimates that herbal medicine is still the mainstay for primary healthcare of about $80 \%$ member states of WHO acknowledge importance of plants for medicinal purposes. The use of botanical raw material is in many cases much cheaper than chemical alternate substances. Consequently, there is an enormous demand for botanicals in domestic use and commercial trade in the international market (S.P. Ghosh 2013). 
A crucial gap exists in current ethno-pharmacological and medicinal plant research which impacts on a wide-range of factors affecting a sustainable, socio-culturally equitable, and safe supply of herbal medicines (Booker et al, 2012). Research about the potential for MAPs development in Badakhshan is especially fragmented and scarce, however certain themes can be found suggesting ways forward using MAPs to increase incomes, link into regional and international markets, and promote sustainable practices. (ICARDA, 2006; Jeppesen et al, 2012; Kassam et al, 2010; Kruse, 2015; Soelberg, 2016; Stanikzai, 2007).

There is an extensive set of reports about useful plants in Wakhan (Soelberg, et al, 2016), some valuable information about wildlife and the socio-economic framework in Darwaz (Moheb, et al, 2012). One must acknowledge the severe imbalance of information about MAPs in other districts of Badakhshan, as there are very few direct references to plants found in other districts. The general literature on MAPs and livelihood improvement suggests that MAPs "have a huge potential for remote communities that practice subsistence agriculture and have limited access to the regional economy" (Sher, 2014; p.2).

This literature review refers to MAPs grown in Badakhshan that could be exploited as alternative income sources for rural and remote communities. The review attempts to provide a foundation for exploring the range and distribution of marketable MAPs in Badakhshan; relevant market activities, trade, and value chains; and community and livelihood considerations. It also suggests that the promotion of MAPs cannot be seen in isolation. Food security, land tenure insecurity, the role of middlemen, and environmental conditions are a few of the issues that could severely impact how successful a MAPs program would be in improving the well-being of the least advantaged and most economically vulnerable in the region. Further a thorough review has already been conducted by Karamkhudoeva et al (under review in Human Ecology Journal) and there is no need in this article to repeat it and further review.

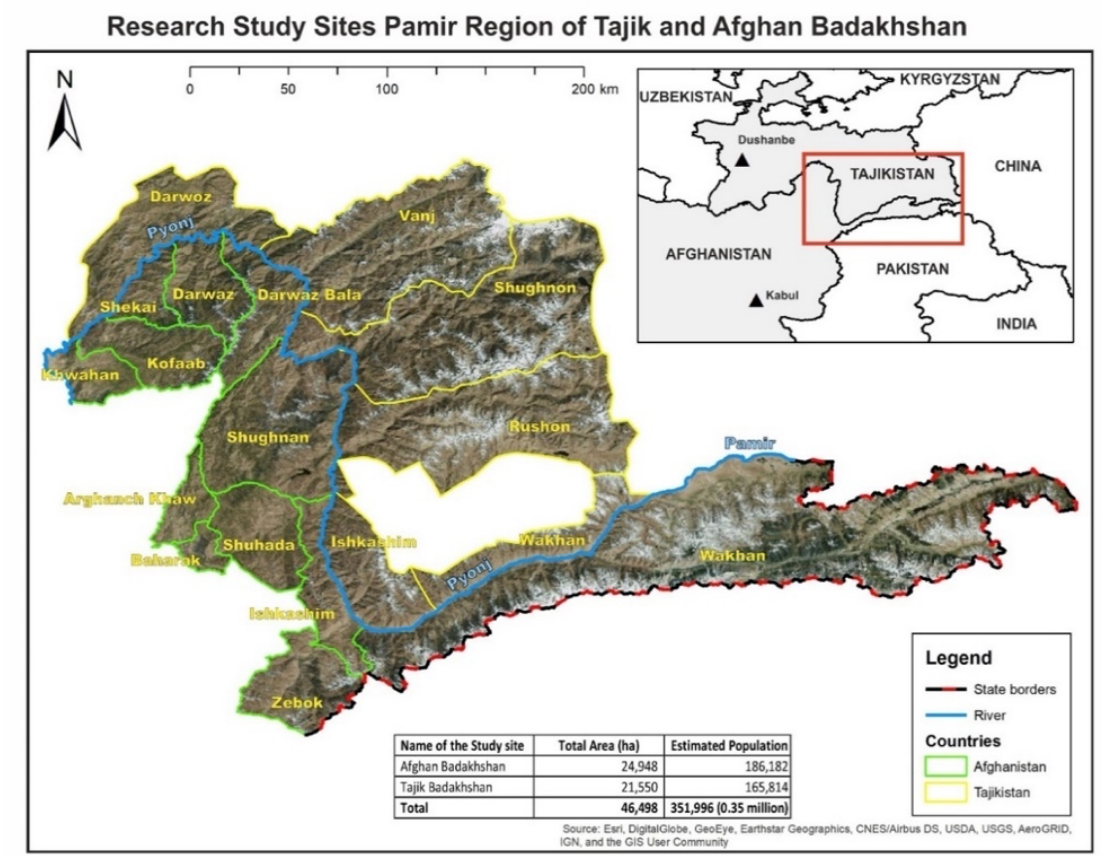

Figure 1. Map of study area

This study attempts to capture and document the indigenous knowledge (IK) system and assess how the IK contributes to biodiversity conservation and social/community resilience in the study area of Pamir region of Tajik and Afghan Badakhshan.

\section{Objectives of the study}

1. Investigate and explore the contribution of farmers' and herders' indigenous knowledge to biodiversity and local food and health system in the study area of Pamir region of Tajik and Afghan Badakhshan.

2. Explore and document traditional knowledge critical to the Pamir region for conservation, adaptation, and resilience of the communities. 


\section{Materials and Methods}

To achieve the above objectives following research tools were designed and field observations and interviews were conducted using the following methodology:

At the very outset, research literature and ancillary data and information on medicinal plants, local knowledge, and other relevant themes inside and outside the region were reviewed to avoid duplication and to determine the research gaps.

Research design: For the field research and investigation, a multi-stage random sampling technique was adopted for selection of research sites. In the first stage research districts were selected randomly in both Tajik and Afghan Badakhshan. In second stage villages/valleys were selected on random basis in both Tajik and Afghan Badakhshan and in third stage households were selected again on random basis. Information on villages, population and household details were collected from provincial statistic departments/offices in both Gorno Badakhshan Autonomous Oblast (GBAO) Tajikistan and Afghan Badakhshan to determine the pool of villages from which the random sample will be selected. The sample size was kept at $20 \%$ in all stages of sampling and surveys because of the vast geographies of the study area.

\section{Data Collection}

For data collection from the field, a structured questionnaire was developed, and 280 individual interviews were conducted in four border districts of Afghan Badakhshan including Zebak, Ishkashim, Wakhan and Shughnan and four districts of Tajik Badakhshan including Shughnan, Roshan, Ishkashim and Wakhan during 2017-18. The respondents were both men (44\%) and women (56\%) ranging from 25 to 75 years old. The interviews were conducted in their own homes, offices, shops, agriculture fields and pastures after obtaining the oral prior informed consent of each participant. The level of education in Afghan Badakhshan was very low particularly among women respondents i.e. 5\% women had completed primary level or had informal education and hardly $10 \%$ of men had primary and secondary education. On the other hand, in Tajik Badakhshan nearly 100\% men and women respondents were literate, mostly at bachelor's level.

Interviewees were asked to name the medicinal plants they know and use. As local names of plants vary from valley to valley and district to district and to avoid this problem and to ensure correct identity of medicinal plants the researcher asked the interviewees to identify the plant using two methods: a) showing the plant they had collected available in their stock, or b) researcher showing color photographs and interviewees recognizing the plant. For further confirmation and correct identification of MAP species the author visited herbarium of Pamir Biological Institute (PBI) Khorog, Tajikistan and confirmed the MAP species with herbarium samples. Moreover, publications on MAPs of Pamir region were thoroughly consulted. During individual interviews and focus group discussion the major enquiries were conducted around current status of indigenous knowledge regarding the use of medicinal and aromatic plants, source of plants- growing naturally or cultivated, change in plant population and how indigenous knowledge is contributing to conservation of biodiversity and natural resources, understanding the change in indigenous knowledge on social resilience of communities.

\section{Focus Group Discussion}

Focus group discussions were also held with relevant professionals and knowledgeable persons in Ishkashim, Khorog and Darwaz area and the same structured questionnaire was used to assess status and conservation related issues and management systems of local biodiversity. The group members were identified through detailed consultation with senior colleagues from Aga Khan Foundation (AKF) Area Offices of Ishkashim of Afghan Badakhshan and AKF Khorog Area Office Tajikistan to engage most knowledgeable people who in some way engage with medicinal plants collection, healers/hakims and local traders of medicinal plants. The information generated in the focus group was discussed and triangulated with the same focus group members and conscious efforts were made to record correct information from the groups.

\section{Market Survey}

Market surveys were conducted both in Afghanistan and Tajikistan to identify the most marketable and valuable MAP species for possible on-farm cultivation of certain species for local income generation particularly for the women farmers. In Afghan Badakhshan, Ishkashim, Shughnan, Baharak and Faizabad markets were surveyed in addition of Kabul National Market. Besides markets survey in Afghanistan, information on MAPs trades were also collected from ministry of trade and commerce government of Islamic Republic of Afghanistan. In Tajikistan the 
major markets covered include Khorog, Roshan, Darwaz, Kulob city and Dushanbe city market beside cross border markets at Tem Shughnan and Rozhvoy Darwaz area.

\section{Results}

Field interviews with 280 individual respondents (of which 157 were women) revealed that the mountain communities in Pamir region are by and large dependent on the natural environment to meet their daily livelihood needs, particularly on plant resources for herbal remedies and food. The collected data showed that the residents in the study area used 128 different plant species belonging to 63 families and 81 genera for health-related issues and food purposes. Among this number, 25 species are included in the official Pharmacopeia of the former USSR (State Pharmacopeia of USSR, 1990).

Sixty-eight plants were listed as being used for food, including for herbal tea, juices, compotes (fruits preserved in syrup), jams, salads, soups, dry fruits, nuts as well as spices (see Annex 1), indicating strong relation and dependency of the communities on medicinal plants resource for both food and herbal remedies in the Pamir region.

Medicinal plants market surveys and assessment revealed that eighty-nine medicinal plant species were mostly traded in local, provincial, Cross Border Markets between Afghan and Tajik Badakhshans along the River Panj and national markets, including licorice roots (Glycyrrhiza glabra L.), black currant (Ribes nigrum L.), stinking gum (Ferula assafoetida L.), black cumin (Bunium persicum Boiss.), mint (Mentha longifolia var. asiatica L.), rosehips (Rosa canina L.), buck wheat (Fagopyrum esculentum Moench.), chamomile (Matricaria chamomilla L.), barberry (Berberis vulgaris L.), Russian olive (Elaeagnus angustifolia L.), caper (Capparis spinosa L.) both in Afghanistan and Tajikistan. Most species were used as food and medicines, and the flower, fruits and roots were the most valuable parts of plants. Sixty species grew naturally within the surrounding vicinities of households that could easily be collected, where the rest was wild collected.

The field interviews with diverse group of respondents including farmers, teachers, pastoralists/plant collectors and housewives revealed that the most demanded and marketable medicinal plant species grew far away from settlements (average 5 to $10 \mathrm{~km}$ ) mostly in the up-hills, mountains, and high pastures. This included black cumin (Bunium persicum Boiss.), stinking gum (Ferula assafoetida L.), black currant (Ribes nigrum L.), and some species of mushrooms like morels (Morchella esculenta L.) indicating the pressure and over-harvesting of the species by the local dwellers in the village surroundings and lower areas. This finding was further confirmed with key informants during focus group discussions at Khorog Tajik Badakhshan, Ishkashim and Nusai districts of Afghan Badakhshan.

During individual interviews in the field, we found that 14 medicinal plant species were also used for ethnoveterinary purposes, especially injuries, menorrhagia, indisposition, and treatment of sensory apparatus in animals (Table 1).

Mentha asiatica Borris (mint), Ribes nigrum (black currant), Nepeta glutinosa Benth (catnips), Glycyrrhiza glabra L. (licorice), Ferula assafoetida L. (hing/kamol), Peganum harmala L. (harmala), Achillea biebersteinii Afan. (yarrow), Berberis heterobotrys $\mathrm{E}$. Wolf (barberry) and Bunium persicum Boiss. (black cumin) were the most collected and traded medicinal plants for home consumption as well as for marketing at local and national level.

Table 1. Plants used for Veterinary medicine purposes

\begin{tabular}{|l|l|l|l|}
\hline $\begin{array}{l}\text { Local Name of Plants } \\
\text { (Tajik/Afghan) }\end{array}$ & English Names & Scientific Names & $\begin{array}{l}\text { Local Uses of medicinal } \\
\text { plants }\end{array}$ \\
\hline Zargul & Barberry & Berberis heterobotrys E. Wolf & For treatment of injuries \\
\hline Khichifkhor/shikastaband & Kind of mint & Nepeta glutinosa Benth & $\begin{array}{l}\text { For treatment of broken } \\
\text { bones }\end{array}$ \\
\hline $\begin{array}{l}\text { Khipekhk/ishqorgiyoh / } \\
\text { Surkhchuk }\end{array}$ & $\begin{array}{l}\text { Horseradish/red } \\
\text { cole }\end{array}$ & $\begin{array}{l}\text { Macrotomia euchroma Royle } \\
\text { ex Benth }\end{array}$ & For treatment broken bones \\
\hline Warkh (oghun) & Prangos & Prangos pabularia Lindl & $\begin{array}{l}\text { Used to remove } \\
\text { endoparasites }\end{array}$ \\
\hline Toji khurus & Cock comb & Celosia cristata L. & $\begin{array}{l}\text { Removal placenta in } \\
\text { animals }\end{array}$ \\
\hline
\end{tabular}




\begin{tabular}{|l|l|l|l|}
\hline Pudina & Mint & Mentha asiatica Borris & $\begin{array}{l}\text { Used against constipation } \\
\text { and GIT disturbance }\end{array}$ \\
\hline Spand & Harmala & Peganum harmala L. & $\begin{array}{l}\text { Animals exposed to smoke } \\
\text { of Aspand to reduce stress } \\
\text { and against evil eye. }\end{array}$ \\
\hline Zirdosk & Yarrow & Achillea biebersteinii Afan. & Used against Diarrhea \\
\hline Ykrob/Shebit & Dill & Anethum graveolens L. & Tympanites and bloating \\
\hline Gilgitak/Angat & Seabuckthorn & Hippophae rhamnoides L. & Conjunctivitis \\
\hline Shirinbuya & Licorice & Glycyrrhiza glabra L. & $\begin{array}{l}\text { Atony, absence of intestinal } \\
\text { peristalsis }\end{array}$ \\
\hline Charog /Sharsham & Mustard & Brassica napus L. & $\begin{array}{l}\text { To decrease body } \\
\text { temperature }\end{array}$ \\
\hline Zegher & Flax seed & Linum usitatissimum L. & $\begin{array}{l}\text { Laxative used for } \\
\text { constipation }\end{array}$ \\
\hline Takhach & Wormwood & Artemisia sieversiana Wild. & $\begin{array}{l}\text { Used for abdominal worm } \\
\text { and dysentery in animals. }\end{array}$ \\
\hline
\end{tabular}

Source: Author's compilation based on data collected in the field.

Based on parts used, the medicinal plants are classified into five categories i.e. flower, fruit/seeds, leaves, roots, and gums with their local usage as shown in Table 2.

Table 2. Categories of medicinal plants based on the Part Used of the plants locally

\begin{tabular}{|c|c|c|c|c|}
\hline $\begin{array}{l}\text { Category of } \\
\text { the Plants }\end{array}$ & $\begin{array}{l}\text { Local Afghan /Tajik } \\
\text { Names }\end{array}$ & English Names & Scientific Names & Local usages \\
\hline \multirow[t]{8}{*}{ Flowers } & Karam & Cabbage & Brassica oleracea L. & $\begin{array}{l}\text { Anti-inflammatory, arthritis, } \\
\text { vegetable /food }\end{array}$ \\
\hline & Jambilak & Blue mint & $\begin{array}{l}\text { Ziziphora pamiroalaica Juz. } \\
\text { ex Nevski }\end{array}$ & $\begin{array}{l}\text { Against high blood } \\
\text { pressure }\end{array}$ \\
\hline & $\begin{array}{l}\text { Rishtakashak / } \\
\text { Ragakwokh / Barge } \\
\text { zuf }\end{array}$ & & Plantago lanceolata L. & $\begin{array}{l}\text { kidney pain, abdominal } \\
\text { obstruction }\end{array}$ \\
\hline & Podina & Mint & Mentha asiatica Boriss. & $\begin{array}{l}\text { Digestion, abdominal pain, } \\
\text { spices }\end{array}$ \\
\hline & Gulkhor & Dog rose & Rosa canina L. & For kidney pain \\
\hline & Ramashka & Chamomile & Matricaria chamomilla L. & $\begin{array}{l}\text { Anti-inflammatory, } \\
\text { sedative, gall bladder aid, } \\
\text { anticoagulant, toothache } \\
\text { aid, gynecological aid }\end{array}$ \\
\hline & Masfar & Saw flower & Carthamus tinctorius L. & $\begin{array}{l}\text { Used for cough, chest } \\
\text { congestion and coloring } \\
\text { dishes }\end{array}$ \\
\hline & Pupaki juvorimaka & Corn silk & Maydis stigmata $\mathrm{L}$. & For jaundice \\
\hline \multirow[t]{12}{*}{ Fruits/Seeds } & Qaraqat / Qot e Siah & Black currant & Ribes nigrum $\mathrm{L}$. & $\begin{array}{l}\text { Decrease blood fat, a } \\
\text { blood cleaner }\end{array}$ \\
\hline & Zargul & Barberry & Berberis vulgaris $\mathrm{L}$. & $\begin{array}{l}\text { Blood purifier, blood } \\
\text { pressure }\end{array}$ \\
\hline & Zeera & Black cumin & Bunium persicum Boiss. & Cold, digestion, food spice \\
\hline & Shibit & Dill & Anethum graveolens $\mathrm{L}$. & Blood pressure, food spice \\
\hline & Gashniz & Coriander & Coriandrum sativum $\mathrm{L}$. & Digestion, food spice \\
\hline & Kadu & Pumpkin & Cucurbita pepo L. & Vegetable/food \\
\hline & Nok & Pear & Pyrus persica Pers. & fruit \\
\hline & $\begin{array}{l}\text { Boqlajan / Bodinjan } \\
\text { e Siah }\end{array}$ & Egg plant & Solanum melongena L. & Vegetable, food, \\
\hline & Gulkhor & Dog rose & Rosa canina $\mathrm{L}$. & For kidney pain \\
\hline & Zardalu & Apricot & Prunus armeniaca $\mathrm{L}$. & $\begin{array}{l}\text { Against constipation, as } \\
\text { fruit }\end{array}$ \\
\hline & Sinjid, Seezd & Russian olive & Elaeagnus angustifolia L. & Diuretic, antipyretic \\
\hline & Chormagz & Walnut & Juglans regia $\mathrm{L}$. & $\begin{array}{l}\text { abdominal obstruction, for } \\
\text { brain improvement, cough }\end{array}$ \\
\hline
\end{tabular}




\begin{tabular}{|c|c|c|c|c|}
\hline & Tut & Mulberry & Morus alba L. & Digestion, kidney pain \\
\hline & Seb & Apple & Prunus malus $\mathrm{L}$. & \\
\hline & Alabolu & Wild cherry & Prunus avium $\mathrm{L}$. & Bronchitis, joint pain \\
\hline & Injeer & Fig & Ficus carica L. & $\begin{array}{l}\text { Indigestion, sore throat, } \\
\text { cough }\end{array}$ \\
\hline & Badam & Almond & Prunus amygdalus Batsch. & $\begin{array}{l}\text { Kidney stone, gall stone, } \\
\text { constipation, oil is used for } \\
\text { dry skin }\end{array}$ \\
\hline & Angat, & Seabuckthorn & Hippophae rhamnoides L. & $\begin{array}{l}\text { Liver aid, gastrointestinal } \\
\text { aid, antibacterial, heart } \\
\text { medicine, gynecological } \\
\text { aid, diabetes medicine }\end{array}$ \\
\hline & Anar & Pomegranate & Punica granatum $\mathrm{L}$. & $\begin{array}{l}\text { Cough, throat problem, } \\
\text { digestion, joint pain }\end{array}$ \\
\hline & Dolana & Hawthorn & Crataegus sanguinea Pall. & $\begin{array}{l}\text { Blood purifier, liver, hear } \\
\text { diseases }\end{array}$ \\
\hline & Koksulton / Aloocha & Plum & Prunus domestica L. & \\
\hline \multirow[t]{6}{*}{ Leaves/Stem } & Pudina & Mint & Mentha arvensis $\mathrm{L}$. & $\begin{array}{l}\text { Blood pressure, digestion, } \\
\text { food spice }\end{array}$ \\
\hline & $\begin{array}{l}\text { Rishtakashak/ } \\
\text { Ragakwokh, } \\
\text { ragwokh }\end{array}$ & & Plantago lanceolata L. & $\begin{array}{l}\text { For injury, kidney pain, } \\
\text { abdominal obstruction, }\end{array}$ \\
\hline & Chokri & Rhubarb & $\begin{array}{l}\text { Rheum emodii Wall. ex } \\
\text { Meissn }\end{array}$ & Blood pressure, spice \\
\hline & Rawash & Rhubarb & $\begin{array}{l}\text { Rheum maximowiczii } \\
\text { Losinsk. }\end{array}$ & \\
\hline & Pudina, Wuthn, & Mint & Mentha asiatica Boriss. & $\begin{array}{l}\text { Blood pressure, female } \\
\text { diseases }\end{array}$ \\
\hline & $\begin{array}{l}\text { Ragakvokh / bargi } \\
\text { zuf }\end{array}$ & $\begin{array}{l}\text { Broadleaf } \\
\text { plantain }\end{array}$ & Plantago major $\mathrm{L}$. & Gastric ulcer, kidney pain \\
\hline \multirow[t]{6}{*}{ Roots } & $\begin{array}{l}\text { Kachalo e } \\
\text { khamkhurak }\end{array}$ & Sunchoke & Helianthus tuberosus L. & $\begin{array}{l}\text { Blood pressure, blood } \\
\text { cholesterol }\end{array}$ \\
\hline & Chosnook/Seer & Garlic & Allium sativum $\mathrm{L}$. & $\begin{array}{l}\text { Cardiovascular diseases, } \\
\text { blood pressure }\end{array}$ \\
\hline & Zardak & Carrot & Daucus carota L. & $\begin{array}{l}\text { Diuretic, used against } \\
\text { urinary stones, kidney pain }\end{array}$ \\
\hline & Lablabu & Beet root & Beta vulgaris $\mathrm{L}$. & $\begin{array}{l}\text { Liver diseases, lower blood } \\
\text { pressure, reduce } \\
\text { cholesterol }\end{array}$ \\
\hline & Kasni/Kosni & Endive, chicory & Cichorium intybus L. & Antimalaria, sunblock \\
\hline & Zargul & Barberry & Berberis vulgaris $\mathrm{L}$. & Broken bones \\
\hline \multirow[t]{5}{*}{ Gums } & Kamol/Rav & Stinking gum & Ferula assafoetida L. & $\begin{array}{l}\text { Anti-inflammatory, } \\
\text { antibacterial, antiviral, } \\
\text { diuretic, tuberculosis aid, } \\
\text { liver aid, oncological } \\
\text { medicine }\end{array}$ \\
\hline & Zhovd (Sinjid, Seezd) & Russian olive & Elaeagnus angustifolia L. & $\begin{array}{l}\text { Diuretic, cough, female } \\
\text { diseases, antipyretic, }\end{array}$ \\
\hline & $\begin{array}{l}\text { Zhovd/Noshnedz } \\
\text { (Apricot gum) }\end{array}$ & Apricot & Prunus armeniaca L. & $\begin{array}{l}\text { Heart diseases and } \\
\text { abdominal obstruction }\end{array}$ \\
\hline & $\begin{array}{l}\text { Zhovd/Noshnedz } \\
\text { (shaftalu gum) }\end{array}$ & Peach gum & Prunus domestica L. & For bronchitis and goiter \\
\hline & $\begin{array}{l}\text { Zhovd/Noshnedz } \\
\text { Alabalu (Cherry } \\
\text { gum) }\end{array}$ & Cherry gum & Prunus avium L. & $\begin{array}{l}\text { For bronchitis and goiter, } \\
\text { blood pressure }\end{array}$ \\
\hline
\end{tabular}

Source: Author's compilation based on data collected in the field. Note: some species of plants are multi-purpose which appear repeatedly in different usage categories of medicinal plants in the table 


\section{Parts of medicinal plants used in number and percentage}

60

50

40

30

20

10

0
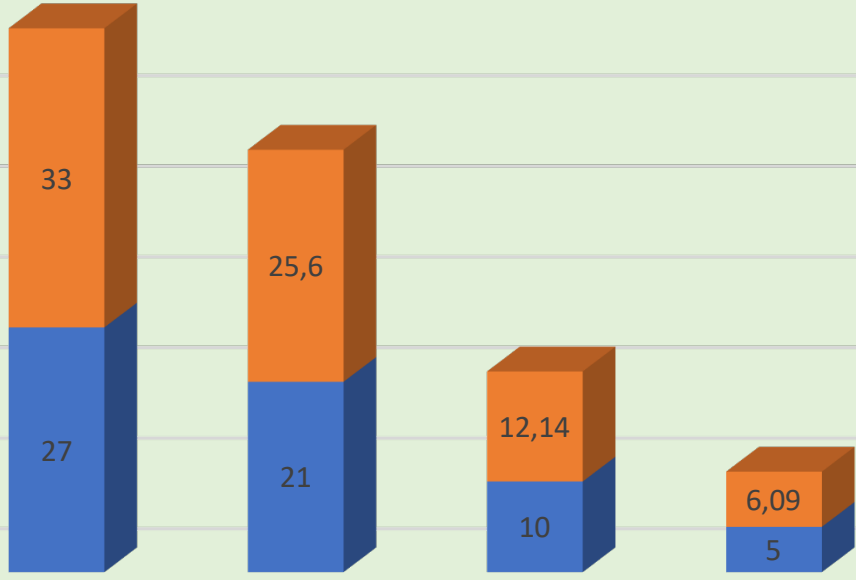

Flower

Fruit/Seeds

Stem/Leaves

Roots

Gum

number \%age

Figure 2. Parts of medicinal plants used in number and percentage

Source: Author's compilation based on data collected in the field.

Figure 2 shows that fruit/seed and stem and leaves were the most common parts of the medicinal plants used for different ailments followed by flowers, roots and gums indicating if irrational and unsustainable harvesting continues there is likelihood that the wild population of majority of medicinal plants species either reduced drastically or may disappear from their natural habitats within a decade.

\section{Distribution of Ethnobotanical knowledge according to gender, age, education and occupation}

Detailed information available for 119 respondents has been analyzed. Summary statistics are shown in Table 3, where 65 female (55\%) and 54 male (45\%) respondents participated in interviews. Their ages ranged from 15 to over 66 years, and majority of both genders were between 35 and 65 years old. Majority of women did not have any formal education (35\%) in comparison to men (16\%), more of whom obtained secondary (13\%) or university (11\%) education. In terms of occupation, women were mostly occupied with housework (39\%), whereas men mostly engaged in farming (16\%) and private sector work like jobs in NGOs (18\%). Interestingly, about equal number of women and men had professional occupations such as running a business, working as a chef, and teaching, though the number of people of both genders occupied thus is very low. Related to the topic of medicinal plants, it is important to highlight that there were seven women as medicinal plant collectors vs. only one man identifying as such.

Respondents listed various plants that they know and use for medicinal purposes. Figure 3 shows a bell-curve shape where majority of respondents (75\%) listed between nine and 15 plants (middle of the curve), while few listed less or more plants (both ends of the curve respectively). Listed plants ranged between five and 23 plants (see $x$-axis). It shows that most local people know about medicinal plants, and while few have little knowledge some know a lot more. This is an important finding because knowledge of medicinal plants is distributed among people, and some may even be experts with greater knowledge.

Interesting patterns emerge when analyzing the number of plants listed by gender, age group, education and occupation (Table 3). While, overall, average number of plants listed is 13 ( $\min 5, \max 23$ ) and both genders listed roughly equal number of plants, females listed greater range of plants ( $\min 7, \max 23$ ) compared to males (min 5 , max 18). Although this may be partly due to greater share of female (55\%) vs male (45\%) respondents, this finding may still suggest that women may have more knowledge of medicinal plants due to their domestic obligations, including caring for the sick, food preparation, and taking livestock to the pastures, where they collect medicinal plants as well. 
Table 3. Summary statistics

\begin{tabular}{|c|c|c|c|c|}
\hline & \multicolumn{2}{|l|}{ Female } & \multicolumn{2}{|l|}{ Male } \\
\hline & $\begin{array}{l}\text { Number of } \\
\text { respondents }\end{array}$ & Percent & $\begin{array}{l}\text { Number of } \\
\text { respondents }\end{array}$ & Percent \\
\hline \multicolumn{5}{|l|}{ Age } \\
\hline $15-24$ & 1 & $1 \%$ & NA & NA \\
\hline $25-34$ & 8 & $7 \%$ & 6 & $5 \%$ \\
\hline $35-50$ & 33 & $28 \%$ & 24 & $20 \%$ \\
\hline $51-65$ & 14 & $12 \%$ & 20 & $17 \%$ \\
\hline 66-over & 9 & $8 \%$ & 4 & $3 \%$ \\
\hline \multicolumn{5}{|l|}{ Education } \\
\hline Informal & 42 & $35 \%$ & 19 & $16 \%$ \\
\hline Primary & 10 & $8 \%$ & 7 & $6 \%$ \\
\hline Secondary & 6 & $5 \%$ & 15 & $13 \%$ \\
\hline University & 7 & $6 \%$ & 13 & $11 \%$ \\
\hline \multicolumn{5}{|l|}{ Occupation } \\
\hline Business & 1 & $1 \%$ & 1 & $1 \%$ \\
\hline Cashier & NA & NA & 1 & $1 \%$ \\
\hline Chef & 2 & $2 \%$ & 2 & $2 \%$ \\
\hline Engineer & NA & NA & 1 & $1 \%$ \\
\hline Farmer & NA & NA & 19 & $16 \%$ \\
\hline Housewife & 47 & $39 \%$ & NA & NA \\
\hline Med. plant collector & 7 & $6 \%$ & 1 & $1 \%$ \\
\hline Nurse & 1 & $1 \%$ & NA & NA \\
\hline Pastoralist & NA & NA & 4 & $3 \%$ \\
\hline Private sector & 3 & $3 \%$ & 21 & $18 \%$ \\
\hline Teacher & 4 & $3 \%$ & 4 & $3 \%$ \\
\hline Total & 65 & $55 \%$ & 54 & $45 \%$ \\
\hline
\end{tabular}

Source: Author's compilation based on data collected in the field. "NA" indicated no data was reported.

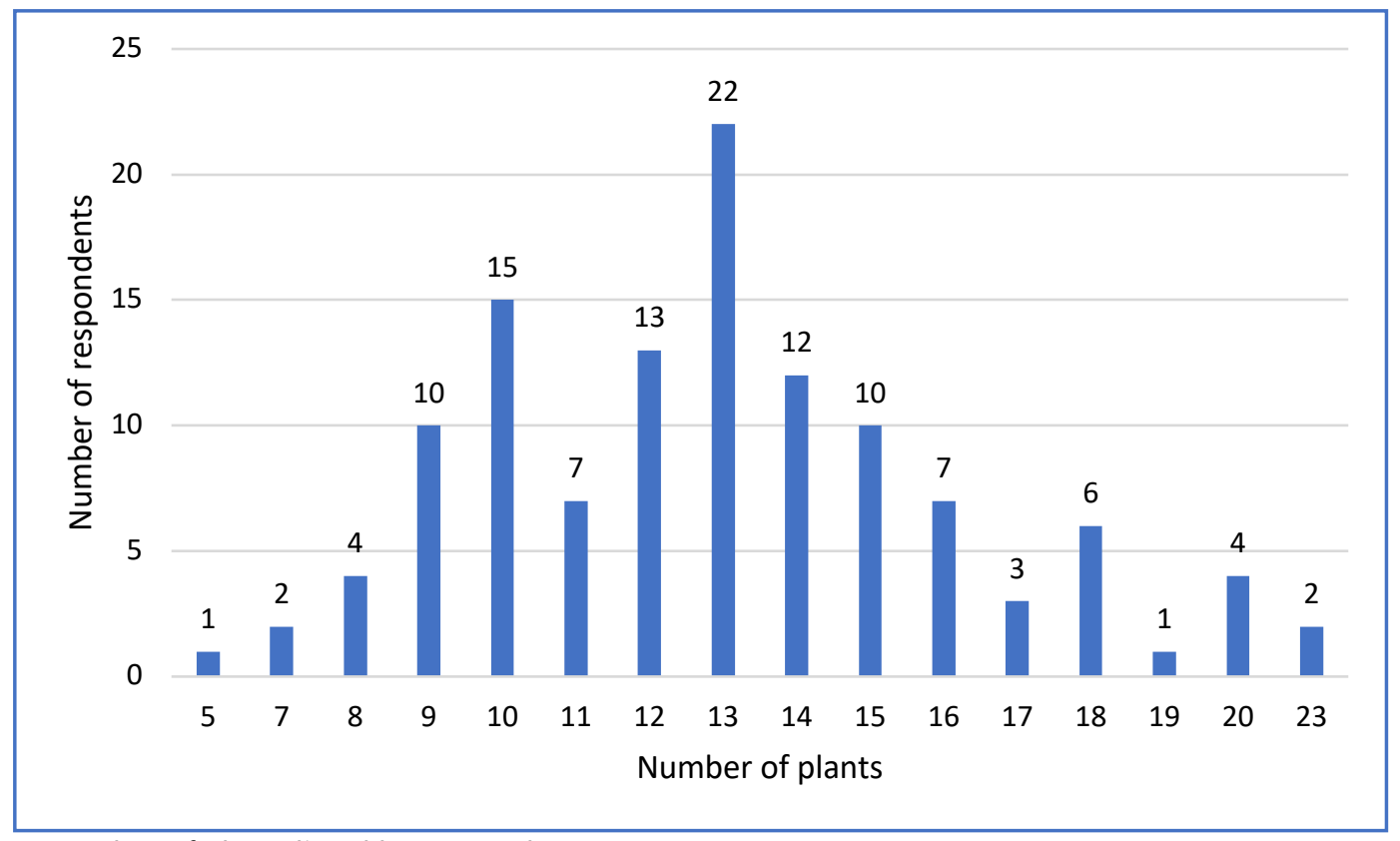

Figure 3. Number of plants listed by respondents

Source: Author's compilation based on data collected in the field. 
In terms of age group, greater number plants were listed by those in their middle age and the elderly. This may suggest that more knowledge of medicinal plants comes with greater experience. However, it may be misleading because the younger age groups are not represented in this study (only one respondent in 15-24 years age group).

Level of education does not seem much to effect knowledge of medicinal plants; however, it is noteworthy that those without any formal education listed the maximum number of plants (23 plants). It should be noted that more than half of respondents (51\%) did not have any formal education, which can be interpreted as diluting the effect of education. But this may not be necessarily the case given the reality of Afghanistan where educational attainment is very low due to lack of incentives in terms of well-paid formal jobs as well as the fact that local knowledge of medicinal plants does not come from formal education. Evidence for the latter can be seen in the findings of occupation that comes next.

In terms of occupation, it is very remarkable that housewives listed the greatest number of plants along with the medicinal plant collectors, about half of whom (seven out of 13) were female. Besides, farmers and pastoralists as well as those working in private sector and teaching occupations also listed more plants. While the former may have direct access to the medicinal plants due to their proximity to the environment and working in the field, which can explain the breadth of their knowledge, the reasons for teachers and private sector workers remains unknown (as this was not explicitly asked during interviews). Nonetheless, it should be noted that housewives (39\%), private sector workers (20\%), and farmers (16\%) are more represented in this study compared to other occupations, which may contribute to these aforementioned findings. At the same time, as with education, lack of opportunities to engage in other occupations is part of the realities of living in Afghanistan, and therefore, the findings reflect the realities on the ground.

\section{Effect/impact of indigenous knowledge on plant biodiversity}

Biological diversity is the variability among living organisms from all sources including, inter alia, terrestrial, marine and other aquatic ecosystems and the ecological complexes of which they are a part, this includes diversity within species, between species and of ecosystems (CBD 1992). The notion of biodiversity is pertinent here as the Pamir region is a hub of a unique and diverse flora and fauna upon which food, medication and general livelihood of people depend, and on which many traditions, rituals and cultural practices are based. However, field observations and interviews of respondents in the study area revealed that there was a general trend of a decrease in number of plants in natural environment as $46 \%$ of responses indicated that around 50 medicinal plant species have decreased over the last 15 years from surrounding of villages and natural habitats. Field interviews also support this finding, as around $40 \%$ of medicinal plant species receded to far flung mountains and high- altitude pastures from plain and lower areas of many village vicinities in the study districts.

Ninety six percent of the people in Afghan Badakhshan (OCHA 2015-16) and 86\% people in Tajik Badakhshan are living in rural areas (world data atlas-Tajikistan) and the population of both Tajik and Afghan Badakhshans is heavily dependent on natural environment for their livelihoods particularly for fuelwood energy. In Afghan Badakhshan during the three decades of civil war and lawlessness, forest resources were heavily exploited by the local people and nomads without any restriction or regulation either from government or from the local communities. Precious pistachio, almond and juniper forests with other small woody vegetation were destroyed for fuel purpose. Even now the remnants of junipers, birch, and other small bushes are being extracted by local dwellers not only for fuel purpose but also to earn money by selling the bushes in local market. One donkey load of worm wood (Artemisia maritima L.) and Saxual (Haloxylon griffithii subsp. wakhanicum) was being sold for 250 Afghani (US\$3.3) without any check. Consequently, there is annual flash floods and landslides which are damaging agriculture and other vital infrastructures (Personal observations in the field).

In Tajik Badakhshan, though the situation of forest and rangelands is comparatively better than on the Afghan side, the removal of vegetation for fuel purpose and land degradation are on-going. During Soviet times, external energy supplies (electricity, coal) were provided almost free of charge, which led to de-connection from local available resources and an artificial increase in both human and livestock population (Andrea et al. 2007). After independence in 1991 the state energy supply ended abruptly, forcing people to rely on local resources (Hoeck et al. 2007). This abrupt change in energy supply had a negative affect with compelling local people to switch to local biomass collection for fuel energy purpose which led to deforestation and collection of bushes from the mountain slopes.

In the Eastern Pamir mountains, the people have almost overexploited the slow growing shrubs Teresken (Ceratoides papposa Botsch \& Ikonn) and Artemisia maritima L., negatively impacting the mountain pastures, as 
these plants have a role in capturing rainwater and protecting soil from erosion and landslides. The plants also provide much needed forage to livestock of the local population and wildlife during prolonged winter months.

There was increasing awareness and understanding about biodiversity and medicinal plants among community members, as 15 years prior less than $40 \%$ of village people in the study area knew about medicinal plants that were found locally. This is now increased to $60 \%$ villagers knowing about medicinal plants and their importance for herbal remedies and as local source of income. Similarly, household interviews revealed that 15 years ago roughly $40 \%$ of the villagers used medicinal plants and now $60 \%$ of the villagers used local medicinal plants for human ailments. There were not any written materials available with local communities on MAP uses, rather the traditional knowledge of medicinal plants passed down from generation to generation is being maintained by few members in communities and at household levels. Thus, increasing knowledge, awareness and understanding about biodiversity is improving social resilience of the mountain communities in Pamir region.

This temporal change in knowledge and awareness about the importance of medicinal plants by local communities has both positive and negative implications. The positive implication is that knowledgeable people harvest, use, promote and/or conserve medicinal plants in their natural habitats for sustained supply and accruing continuous benefits from the available medicinal plant resource. The negative implication may be that of increasing market demand, overharvesting and more pressure on wild medicinal plants, resulting in depletion and/or extinction of certain medicinal plant species in the localities.

Indigenous knowledge of local communities on medicinal plant usage for food, therapeutics and traditional rituals was found to be a key factor for community/social resilience as well as in preservation of important medicinal plant species within the farmlands and natural environment. Indigenous knowledge is defined by International Council for Science (ICSU) as "a cumulative body of knowledge, know-how, practices and representations maintained and developed by peoples with extended histories of interaction with the natural environment". These sophisticated sets of understandings, interpretations and meanings are part and parcel of a cultural complex that encompasses language, naming and classification systems, resource use practices, ritual, and spirituality.

Recognizing the traditional or indigenous knowledge of local communities of their environmental resources, conservation and cultural practices has great implications in participatory and sustainable management of available resources including medicinal plants and biodiversity. Over $89 \%$ of responses indicated that the factors contributing to the conservation of plants were education on indigenous knowledge of plants, the traditional usage of plants for medicine and food, spirituality, and some local rituals, e.g. to ward off demon and evil spirit from the houses. Thus, the usage of medicinal plants and associated indigenous knowledge are key factors for community resilience in the mountain environment of the Pamir region.

All respondents in the study area felt that the indigenous knowledge about plants usage and conservation was increasing because of improved education, health consciousness, increasing demand for organic products i.e. medicinal and aromatic plants (MAPs) in local and national markets. Thus, education on indigenous knowledge (IK), retaining it through proper documentation and passing it down to the young generation is important for social resilience.

Sixty-six percent of respondents felt that forest resources had increased over the past 15 years in some of the districts like Ishkashim, Wakhan, Zebak, Baharak and Shughnan districts of Afghan Badakhshan due to intensive tree plantation and forestry development program undertaken by Aga Khan Foundation (AKF) Badakhshan program. In Tajik Badakhshan the forest resources are under the control of the government forest management committee, however, a small portion, around 20\% forest lands, is given to the interested individual families in Gorno Badakhshan Autonomous Oblast (GBAO) on nominal rent i.e. 70:30 \% farmer to government for management of the resource on sustained basis.

Currently there is no on-going forest rehabilitation work in government-controlled forests, while in leased forest land the government forest department has provided some initial funding to the farmers for protecting or fencing the specified forest parcels, as well as technical guidance. Thus, some rehabilitation and improvement of forestry is on-going in leased and protected forest sites in Tajik Badakhshan. As per the interviews with both government officials and village respondents, the government-controlled forest land is currently not managed properly, and forest degradation is on-going, while in contrast the leased forest lands are well managed by the families/farmers. 
Fifty nine percent of respondents felt that the population of medicinal and aromatic plants had increased in terms of visibility, availability, and accessibility, especially because of sporadic rainfalls in summer months (unusual rains in dry season - effect of climate change). There is however increasing demand in local markets for medicinal plants and more people particularly the poor men and women are engaged in collection and selling of medicinal plants both Tajik and Afghan sides of the study area.

Forty four percent of respondents felt that pasture and grazing land had deteriorated over the last 15 years on the Afghan side. Discussion with the respondents revealed that on the Afghan side there was no proper pasture resource management system in place, neither by the custodian government department, nor by the communities themselves. There was free and uncontrolled grazing on all major pastures in the study areas involving the local as well as nomadic grazers (Kochies). Moreover, around a million animals, mostly fat-tailed sheep of nomadic Kochies, are coming annually from Baghlan, Kunduz and Takhar provinces to Badakhshan because of the usufruct rights for pastures given to the livestock owners by the then Afghan government and utilizing the summer pastures intensively. However, on the Tajik side pastures are comparatively in better condition, and medicinal plant production, collection and marketing were reported as increasing at local and national levels. The increase in production of medicinal plants in the pasture and mountains slopes and increases in marketing can also be attributed to changing pattern of weather (sporadic rainfall during summer/dry season) and increasing education and awareness among the people for consuming pure natural products for better health and treatment of human ailments through herbal remedies.

Forty-seven percent of respondents felt that water sources had decreased over the past 15 years, which can be attributed to climate change, i.e. increased temperature and warmer weather conditions being observed by the farmers over a couple of years. Consequently, the glaciers in the mountains are receding, low precipitation in winter months in the form of snow, reducing availability and supply of spring water as observed and mentioned by respondents during individual household interviews. Further increasing human population, bringing more barren areas under cultivation for agriculture and food production could be another important causative factor of the decreasing water resources in the study area.

\section{Effect/impact on Social/Community resilience}

Seventy-five percent of survey respondents reported that traditional water management systems existed and were operational. In Afghan Badakhshan, the traditional water distribution and management system operated by "Mir Joye" or "Mir-e-Aab" (Head of water channels or Head of water) was very strong and effective system and still operating but not that much effective now. Most of the water related infrastructure and management system is being developed by Government Ministry of Water \& Energy (Min-WE) as well as Ministry of Agriculture, Irrigation \& Livestock (MAIL) in close collaboration with international organizations and donor agencies. In Tajik Badakhshan, the water management is controlled by the government water department through "Mir Joye" or "Mir-e-Aab" and community water user associations. Built on the traditional water management systems in both Tajik and Afghan Badakhshan, water user associations have been established and for the collective management of water resources, monthly fees are collected from members of water users and kept in separate bank accounts for maintenance of water channels. Another study in the same region on collective water management used a term "hydrosocial arrangement" here the social components include actors and organizations, human relations and interactions, and regulatory institutions. Irrigation regimes are custom-tailored, contingent configurations that are purposefully negotiated, developed, constructed, maintained, and reproduced by self-organized actors. They can be adapted to shifting social and ecological conditions. Such system / regime is called "hydrosocial arrangements"(Dorre et al 2018). Thus, the traditional and indigenous system of water management is still working and supporting social resilience.

Sixty six percent of survey respondents reported that current forest management systems were either in place or had been replaced with better functioning systems. In Afghan Badakhshan due to a prolonged civil war and lack of a management system, the natural forests of Junipers (Juniperus communis L.), birch (Betula utilis D. Don.), wild pistachio (Pistacia vera L.) and almond (Prunus amygdalus Batsch.) were destroyed mainly for fuel purposes. Because of vague land tenure systems still in place in Afghanistan, the forest resources are considered common property, everyone has access and there is no control mechanism in place to protect natural forests in Badakhshan. However, through the government support and with the interventions of some development organizations, including the Aga Khan Foundation Afghanistan, the communities of Badakhshan have started rehabilitation of the forest resources as well as carrying out reforestation and afforestation programs. In Tajik Badakhshan, the situation and status of forestry is far better than in Afghan Badakhshan, although forest degradation still exists. Forests are 
controlled by the government forest department, and to give some relief and support to local communities, the forest department has privatized around $20 \%$ of forest land to interested farmers for better management of forests resources. Field interviews and discussion with some government officials revealed that the condition and status of privately owned forests are far better than the government-controlled forests areas. It is because of the interventions and better management of forest lands by the private owners, which is encouraging.

All the respondents from Tajik Badakhshan indicated that traditional pasture and land management systems no longer exist or were functional but had been replaced by an alternate pasture/grazing management system. Before the independence of Tajikistan in 1991, management of rangelands and pastures resources were controlled and managed through soviet collective farming system (Kolkhoz), which was not sustainable system rather highly subsidized and dependent on import of fodder and animal feed from distant places in the plains or even from Osh, Kyrgyzstan. After the independence this subsidized system collapsed, herds were broken up, and animals were distributed among the members of collective farms having no experience in pasture management (Umarov 1998). Currently rangelands and pasture resources are overseen by the government department of livestock and pasture management, which is not strong and effective mainly due to lack of resources. However, communities are looking after pastures in their own territories. In Afghan Badakhshan the pasture resources were managed well through local traditional management system, as over two decades of war has not only damaged the government institutions but also negatively affected the local traditional resources management systems. Due to lawlessness and uncontrolled grazing and uprooting of woody vegetation for fuel purposes most of the pastures are overutilized and have deteriorated. However, through the support of government and international development organizations efforts are underway to rehabilitate the pasture resources engaging communities (community Development Councils - CDCs) to restore and improve the natural vegetation and carrying capacities of the pastures.

Eighty four percent of respondents reported that an alternate wildlife management system has replaced the older non-functioning system. During the Soviet period, in Tajik Badakhshan wildlife was managed and protected throughout, even in the very remote areas. However, during this period hunting was common, with even protected wildlife species being hunted by military personnel. Local, non-military individuals and other groups were not allowed to hunt and were severely punished for any kind of hunting activities (Academy of Science et al. 1988). Currently wildlife is managed by the Nature Protection Committee of Tajikistan. Trophy hunting is now conducted annually, and the nature protection committee issues permits to some international hunting companies. However, the custodian local communities feel that they are not given their due share of the income from trophy hunting. In Afghan Badakhshan, there was a good forest and wildlife management system in place under the ministry of agriculture prior to the civil war. Many tourists used to visit Afghan Badakhshan particularly the Wakhan Valley to watch unique wildlife species such as Afghan Urial (Ovis vignei cycloceros Hutton.), Marco Polo sheep (Ovis ammon polii), Snow leopard (Panthera uncia Schreber.), Ibex (Capra ibex L.) etc. However, unfortunately the prolonged war and post-conflict situation had a highly negative impact on wildlife resources due to lawlessness and free hunting, as availability and accessibility to automatic rifles including AK47 for anybody who wanted one, boosted overall individual hunting. Another reason of the decline of wildlife mentioned by the respondents was more human and livestock population and habitat fragmentation by the increasing population. Currently government has controlled hunting in major districts where government has writ, but the situation is still the same in the districts which are under the control of insurgents. Some international development and environmental organizations such as Aga Khan Foundation (AKF) and Wildlife Conservation Society (WCS) are working in Afghan Badakhshan with local communities for protection and sustainable management of nature and environmental resources.

Fifty-nine percent of respondents reported that an alternate Ashar / community self-helping system has replaced the older well-functioning system. Although the community labor system / Asharstill exists in Afghan Badakhshan but is now not as effective as it was 30 years back. There are stories that there was no cash economy, most of the landowners in Badakhshan were not used to hire labor for harvesting crops, fruits and even for construction works for making houses, as there was good self-helping system of Ashar among the community. Ashar was much effective particularly for communal resources management related work such as construction of schools and other buildings including mosques, annual cleaning of irrigation channels, road restoration/clearing after floods and forests or pasture collective management. Further community sharing of available resources like bulls for plowing, donkeys for transportation of harvest to home, sharing animals for threshing and taking sick persons to hospital from far flung villages were common practices. For harvesting of crops like wheat, it takes 3-4 days for each individual farmer to harvest 0.3 ha field but if you invite 10 to 15 farmers as part of the Ashar the work will be done within few hours, with the cost of one-time meal being provided by the farmer. This dependency on each other 
and collective action not only used to make life easy for the communities, but it also used to strengthen social cohesion among communities. This unique traditional Ashar system of self-help and collective action is no longer a common practice in a major part of Afghan Badakhshan, however, in some remote valleys the practice is in vogue but on a small scale.

In Tajik Badakhshan, previously the Ashar system was well functional, as government used to set a date to work in collective farm without any compensation, albeit food was served to all participating people in collective actions. Close neighbors and relatives were invited to help in harvesting and/or construction work and people used to help each other. However, the situation has changed and now everyone engages paid labor, and Ashar is seldomly practiced in most districts of Tajik Badakhshan.

Ninety-one percent of respondents reported that an alternate health security system has replaced the older nonfunctioning system. In Afghan Badakhshan, the health system 25-30 years ago was deplorable. There were no or limited roads, hospitals, and health facilities for most of the districts and people were mostly depended on local herbal remedies for treating of ailments. They used to go to local Tabibs / healers and get treated with herbal products which were not very effective. Consequently, there was high mortality rate particularly among women and children in Badakhshan. This is only discussion and responses on interviewees however there is no strong data to proof this claim of respondents. Now through the support of government, international development organizations and donor agencies the situation has improved in the province. Every district has road connection, a network of link roads to sub-districts and valleys and basic health facilities are available in district head quarter and major towns of the districts. Contrary to Afghan Badakhshan, the health facilities in Tajik Badakhshan were much better during the Soviet era, when free standard medical facilities were available in each major town of GBAO districts and annual health checkups for individual persons was mandatory. However, in the post-Soviet era health facilities exist only in the major towns of Tajik Badakhshan, while the remote valleys and villages still have problems with access to health centers/hospital due to road blockage and transportation issues. The government of Tajikistan and international development organizations including Aga Khan Health Services (AKHS) Tajikistan are extending health facilities through establishing laboratories/diagnostic centers in major towns and conducting vaccination program against common human contiguous and infectious diseases. However, with limited available human and financial resources it is a big challenge for the government and AKHS to run the existing set up on sustained basis and to expand and upscale the health facilities to more communities in Pamir region.

Sixty eight percent of the respondents also added that strengthening local organizations or Shuras financially and technically would be important and contribute more to community/social resilience. The respondents were of opinion that Community Development Councils (CDCs) in Afghan Badakhshan and Social Unions for Development of Village Organizations (SUDVOs) in Tajik Badakhshan, developed by Aga Khan Foundation (AKF) Afghanistan and Mountain Societies Development Support Program (MSDSP) Tajikistan respectively with the relevant national governments are the best platforms for community development, as all village related issues, problems and development needs are discussed here, and solutions to problems are sought using this platform. There is need to strengthen these platforms technically and financially. Technical support needed is around new and innovative technologies, improved farming practices and introducing high yielding crop varieties, controlling diseases and insect pests of crops. Financial support is most important for the organization through either membership fees supported with an endowment fund, as some of the communal issues and problems need immediate actions which cannot be taken without financial footing of the organization. For example, during growing season if there is damage to irrigation channel due to flood and/or landslides the crops of whole communities will suffer unless immediate necessary measures are taken to restore the water supply to the crops within a short crucial period. For such type of time sensitive activities and emergencies CDCs and SUDVOs must have enough fund to take necessary action on time.

\section{Discussion}

The World Health Organization (WHO) estimates that herbal medicine is still the mainstay for primary healthcare of about $80 \%$ member states and WHO acknowledges importance of plants for medicinal purposes. The use of botanical raw material is in many cases much cheaper than to use chemical alternate substances. Consequently, there is an enormous demand for botanicals in domestic use and commercial trade in the international market (S.P. Ghosh 2013). MAPs are botanical raw materials that are primarily used for therapeutic, aromatic and/or culinary purposes as components of medicinal products, health foods and other natural health products (ITC). Plant based herbal medicines have been used for thousands of years in many parts of the world. The therapeutic use of herbal medicines is gaining considerable momentum in the world during the last decade. 
The Pamir region is home to a multi-ethnic population that faces extreme poverty and is closely connected to the land. Despite the availability of high quality and marketable medicinal and aromatic plant species and valuable indigenous knowledge about how local plants are used as medicine and to generate income out of MAPs at local level, the primary producers and collectors of wild MAPs receive a relatively small share of returns because of insufficient knowledge of market chains, lack of processing facilities, inadequate quality control, and other factors.

The findings of the study indicate that there was a sizable decrease in the number of medicinal plants in their natural habitats over the past 15 years. Similar findings were reported by another study indicating that medicinal plants that were abundant 15 years ago in mountains and near grazing lands are now disappearing rapidly, and with each passing year, community members are forced to travel further into the mountains to collect medicinal plants for family needs (Karamkhudoeva M. 2017). However, at the same time we found that there was an increase in knowledge and understanding about biodiversity and importance of MAPs, as hardly $40 \%$ people in the study area knew and used medicinal plants 15 years ago, however now 60\% people know about the importance and benefits of MAPs in the study area. The decrease in certain MAPs populations could directly be attributed to the awareness of people about the importance and benefits of the MAPs, which led to over-harvesting of certain species of MAPs. Secondly, most of the MAPs grow in marginal lands, forest and high mountain pastures, which are communal land and free access to all villagers without any restriction or control, which leads to overharvesting of MAPs by the local dwellers as well as plant collectors.

There is enough evidence from the field study that indigenous knowledge of the usage of plants for medication/herbal remedies, food and cultural rituals has an important role in conservation and sustainable management of the certain MAPs in their natural habitat as well as in homesteads. As findings of a similar study in the same region reveals the indigenous knowledge of medicinal plants is fundamentally dependent on its use. Knowledge is not embedded in people's minds, but in the environment with which they engage. Medicinal plants that people collect but do not grow are a meaningful indicator of indigenous knowledge of local communities (Kassam 2009). With the passage of time people getting better education and health consciousness due to access to information through internet and awareness created by several development organizations active in the study area. Thus, there is a strong culture and trend to conserve certain MAPs both in natural environment and homestead for certain MAPs by the local people in Pamir region, which is not only contributing to conserving local biodiversity and associated knowledge, but also providing a good leverage for improved social resilience of the communities.

Information on policies and legislation affecting botanical species management is lacking, and several authors suggested that policy supports are not in place to encourage a thriving MAPs industry (Stanikzai, 2007). Kruse indicates that legislation is increasing but is not specific about details. He suggests that greater awareness of the complex and increasingly stringent health and safety regulatory requirements in the main developed country markets must be met (Kruse, 2015). Lack of clear and specific government policies for MAPs is a serious challenge and primary cause of difficulties as perceived by MAPs collectors and dealers (Sher et al 2014).

There were some contradictory findings on status and trend of MAPs, forest, pasture, and water resources. Some study area respondent's opinions indicated a declining trend while in other areas the respondents indicated a better and increasing trend. This contradicting information can be attributed to geographical variation, existence of micro-climatic conditions, aspects, climate change related issues and changing weather pattern. The increase in forest resources in some areas can be attributed to increasing awareness among the communities for conservation of forest resources and contribution of some international development organizations in afforestation, pasture management and watershed rehabilitation.

The increase of MAPs in some study areas could be attributed to community awareness, controlled grazing better management of pastures and climatic conditions mainly associated to increased precipitation, as some areas are getting unusual, very localized rains particularly in late spring and summer season, making environment conducive for more vegetation and MAPs production.

Deterioration of pastures and depletion of water resources in some study areas were due to climatic conditions, as grazing lands/pastures and water resources are directly linked with precipitation. If there is good snowfall in winter and rainfall in spring and summer, then there is a good stock of snow and glaciers in the high mountains and more water available in streams and rivulets besides increased aquifers in summer season. Similarly, grazing lands and pastures are directly influenced by precipitation, more snow and rains mean more greener pastures and increased availability of fodder and other vegetations including MAPs. This inference is also supported by more than $50 \%$ of 
the respondents in the study area during field interviews that vegetation, fodder production in the pasture and number and quantity of medicinal plants in the high mountain slopes and pastures directly link with annual precipitation in the study area.

In the scenario of changing traditional resources management system as well as climate change the resiliency of community is apparently increasing. The local traditional systems in water management are still in place and functional in the study areas. Traditional pastures, forest and wildlife management system changed and replaced with new systems and are functioning well. Similarly, the old non-functioning system of Ashar / community selfhelping is replaced with new system (Shuras / village organizations) for collective action is well functioning and communities now are in a better position to help each other as well as for collective management of common property resources. Better health and communal fund management system can be put in place to help communities in time of needs. However, all the respondents were of opinion that education, training, and awareness creation were the most important factors for social/community resilience in the study area.

\section{Conclusion}

Mountain communities in Pamir region are by and large dependent on the natural environment to meet their daily livelihood needs, particularly on plant resources for herbal remedies and food. The collected data showed that the residents in the study area used 128 different plant species belonging to 63 families and 81 genera for healthrelated issues and food purposes. Sixty-eight plants were listed as being used for food, including for herbal tea, juices, compotes (fruits preserved in syrup), jams, salads, soups, dry fruits, nuts as well as spices. Eighty-nine medicinal plant species were mostly traded in local, provincial, Cross Border Markets between Afghan and Tajik Badakhshans along the River Panj and national markets. Sixteen medicinal plant species were also used for ethnoveterinary purposes, especially injuries, menorrhagia, indisposition, and treatment of sensory apparatus in animals.

Both Tajik and Afghan Badakhshans are heavily dependent on natural environment for their livelihoods particularly for fuelwood energy. In Afghan Badakhshan during the three decades of civil war and lawlessness, forest resources were heavily exploited by the local people and nomads without any restriction or regulation either from government or from the local communities. Precious pistachio, almond and juniper forests with other small woody vegetation were destroyed for fuel purpose. Whereas in Tajik Badakhshan, though the situation of forest and rangelands is comparatively better than on the Afghan side, the removal of vegetation for fuel purpose and land degradation are also on-going.

There was increasing awareness and understanding about biodiversity and medicinal plants among community members, as 15 years prior less than $40 \%$ of village people in the study area knew about medicinal plants that were found locally. This is now increased to $60 \%$ villagers knowing about medicinal plants and their importance for herbal remedies and as local source of income. Similarly, household interviews revealed that 15 years ago roughly $40 \%$ of the villagers used medicinal plants and now $60 \%$ of the villagers used local medicinal plants for human ailments.

Indigenous knowledge of local communities on medicinal plant usage for food, therapeutics and traditional rituals was found to be a key factor for community/social resilience as well as in preservation of important medicinal plant species within the farmlands and natural environment. The indigenous knowledge about plants usage and conservation was increasing because of improved education, health consciousness, increasing demand for organic products i.e. medicinal and aromatic plants (MAPs) in local and national markets. Sixty eight percent of the respondents also added that strengthening local organizations or Shuras financially and technically would be important and contribute more to community/social resilience.

Analysis of gender, education and occupation reveals that women, middle age to elderly, those without formal education and engaged in housework or working on the land appear to possess more knowledge of medicinal plants. This is an indication of local knowledge of medicinal plants that rests with females, is accumulated over time, is not much affected by formal education, and is generated through being imbedded in one's ecology. In turn, these findings point towards giving importance to these aspects when considering leveraging local knowledge for health benefits and conservation of medicinal plants. For example, it can be suggested that transmission of knowledge to younger generation should be prioritized as this knowledge may be lost with the passing away of older generation. Moreover, imbedding teaching about medicinal plants into formal education may be a fruitful endeavor as well. Female knowledge holders and those working on the land should receive greater attention and support in transmission of knowledge as well as conservation of plants given their unique advantages of knowledge 
assets and proximity to the environment. Ultimately, plants are important sources of livelihood for local people and their conservation and sustainable use should be an integrated strategy that helps improve people's quality of life, especially, in such locations as the war-torn Afghanistan, where government support and external provisions are far and few, and people rely on natural resources to survive.

Besides climate change related issues, the increasing and continued biotic and anthropogenic pressure on MAPs with prevailing inappropriate and unsustainable collection/harvesting practices further deteriorates the precarious conditions of MAPs in the Pamirs. The rapid depletion of MAPs from the natural environment may negatively impact traditional health systems and food security of poor mountain communities. Thus, there is a need to develop a range of participatory adaptation and conservation strategies for the larger interest and the benefits of present and future generations of mountain communities in the Pamirs.

\section{Declarations}

List of abbreviations: AKF: Aga Khan Foundation; AKHS: Aga Khan Health Services; CBD: Convention on Biological Diversity; CDCs: Community Development Councils; GBAO: Gorno Badakhshan Autonomous Oblast; IK: Indigenous knowledge; Min- WE: Ministry of Water and Energy; MAPs: Medicinal and Aromatic Plants; MAIL: Ministry of Agriculture, Irrigation \& Livestock; MSDSP: Mountain Societies Development Support Program; MSRI: Mountain Societies Research Institute; OCHA: United nations Office for the Coordination of Humanitarian Affairs; SUDVOs: Social Unions for Development; UCA: University of Central Asia; USSR: United Soviet Socialist Republics; WCS: Wildlife Conservation Society

Ethics approval and consent to participate: The author discussed with individual and groups before the interviews and oral permission was obtained from all participants prior to each interviews/discussion in every village in the field.

Consent for publication: The manuscript contains original field investigation/interviews and photographs of plants mostly from natural environment and two photos local herbalists for which oral consent/permission was obtained from the relevant quarters and any information taken from any report is given with proper references.

Availability of data and materials: The data sets and report generated are available for interested researchers, students, and institutions upon request

Competing interests: About this research work the author has no relevant financial or non-financial interest to disclose.

Funding: This research work was conducted during my assignment with AKF Afghanistan as side business during my field work both in Afghan and Tajik Badakhshan. Thus, no specific funding was allocated for this research work. Authors contributions:

Not applicable

\section{Acknowledgements}

This study carried out in cross border districts of Tajik and Afghan Badakhshans along the River Pyonj over five years. The author gratefully acknowledges the individuals and groups of respondents in Ishkashim, Zebak, Shughnan and Nusai district of Darwaz Badakhshan Afghanistan and Khorog, Porshenev, Garam Chashma Ishkashim, Roshan for their generosity in sharing knowledge, information, and time during the field surveys and study. Staff members of Area offices of Ishkashim, Shughnan and Khorog of AKF Badakhshan Afghanistan supported me a lot in organizing individual interviews, focused group discussion and interpretation of local dialects during the interviews, they all deserve appreciation.

My thanks and appreciation are there for my Advisor Prof. Dr. Michael Keusgen of Phillips University Marburg, Germany for his continuous technical guidance, encouragement, and support over the years.

The data analysis and developing the manuscript would not have been possible without generous support from my friend Sameer Dossa of University of Central Asia Bishkek office for his time and help in analysis of the complex data sets, my appreciation and thanks are due to Sameer for his time and support.

I am thankful to Prof. Dr. Rainer W. Bussmann of Ilia State University Tbilisi Georgia for critically insights of the manuscript, valuable comments, and technical guidance in finalizing the manuscripts.

Assistant Professor Murodbek Laldjebaev of Earth and Environmental Sciences Department of University of Central Asia deserves appreciation for his time to review the manuscript and technical support and guidance.

My thanks and appreciation are due to my friend Mrs. Munira Karamkhudoeva of Pamir Biological Institute (PBI) Khorog for her help in identifying local names of different medicinal plant species and interpretation of local dialects during field interviews in Tajik Badakhshan. 
Literature Cited

Academy of Science, Forest Association and Nature Protection Department of the Tajik SSR. 1988. Red Data Book of the Tajik SSR. Dushanbe: Donish [in Russian], 336 pp.

Andrea H, Thomas B, Hans H, Daniel M. 2007. Opportunities and risks in reconciling conservation and development in a post-Soviet setting: The example of the Tajik National Park, The International Journal of Biodiversity Science and Management 3(3):157-169, doi: 10.1080/17451590709618170

Aziz A, Akabirshoeva A 2010. Status and potential use of Medicinal and Aromatic Plants in Pamir Region of Tajik and Afghan Badakhshan: A case study. Aga Khan Foundation, Afghanistan.

Berkes F, Colding J, Folke C 2003. Navigating social-ecological systems: building resilience for complexity and change. Cambridge University Press, New York, New York, USA.

Booker A, Johnston D, Heinrich M. 2012. Value Chains of herbal medicines. Research needs and key challenges in the context of ethnopharmacology. Journal of Ethnopharmacology 140(1):624-633.

Convention on Biological Diversity. 1992. Convention on Biological Diversity. Secretariat of the Convention on Biological Diversity, Montreal, Canada

Dörre A, Goibnazarov C 2018. Small-Scale Irrigation Self-Governance in a Mountain Region of Tajikistan. https://www.jstor.org/stable/90023306?seq=1\&cid=pdfreference\#references_tab_contents

Ghosh SP Dr. Proceedings of workshop on "Expert Consultation on Promotion of Medicinal and Aromatic Plants in the Asia-Pacific Region" Bangkok, Thailand 2-3 December 2013

ICARDA 2006. Medicinal and Aromatic Plants as Alternative Livelihood Sources for Rural Communities in Afghanistan. Jerba, Tunesia.

International Council for Science / Conseil International pour la Science March 2002. Science and Traditional Knowledge: Report from the ICSU Study Group on Science and Traditional Knowledge. Retrieved 24 May 2012.

ITC. https://www.intracen.org/itc/sectors/medicinal-plants/

Hoeck T, Droux R, Breu T, Hurni H, Maselli D. 2007. Rural Energy Consumption and Land Degradation in a PostSoviet Setting - An Example from the West Pamir Mountains in Tajikistan. Energy for Sustainable Development XI (1):48-57

Jeppesen A S, Kristiansen U, Soelberg J, Jager A. 2012. Antihistamine effect of Rubia tibetica, used to treat anaphylaxis caused by tick bites in the Pamir Mountains, Afghanistan. Journal of Ethnopharmacology, 141, 10771079.

Karamkhudoeva M, Laldjebaev M, Ruelle ML, Kassam K.A. 2021. Medicinal plants and health sovereignty in Badakhshan, Afghanistan: Diversity, stewardship, and gendered knowledge (Under review - Journal of Human Ecology)

Karamkhudoeva M. 2017. Revitalization and Retention of Indigenous Knowledge of Medicinal Plants in Afghanistan CAARF Project Policy Brief.

Kassam KA. 2009. Viewing Change Through the Prism of Indigenous Human Ecology: Findings from the Afghan and Tajik Pamirs. Journal of Human Ecology 37:677-690.

Kassam KA, Karamkhudoeva M, Ruelle M, Baumflek M. 2010. Medicinal Plant Use and Health Sovereignty: Findings from the Tajik and Afghan Pamirs. Journal of Human Ecology 38:817-829.

Kassam KA .2009a. Biocultural Diversity and Indigenous Ways of Knowing: Human Ecology in the Arctic, University of Calgary Press, ISBN 9781552382530, Calgary.

Kassam KA. 2010. Pluralism, resilience, and the ecology of survival: Case studies from the Pamir Mountains of Afghanistan. Ecology \& Society 15(2):8. [online] URL: http://www.ecologyandsociety.org/vol15/iss2/art8/.

Kruse W. 2015. Competitive Market Assessment Report for Sea-buckthorn and Liquorice in Afghanistan. USAID / Aga Khan Foundation. Kabul

Gadgil M, Berkes F, Folke C. 1993. Indigenous Knowledge of Biodiversity Conservation, Ambio, 22(2/3):151-156.

Moheb Z, Mostafawi SN 2012. Biodiversity Reconnaissance Survey in Darwaz Region, Badakhshan Province, Afghanistan. WCS Monitoring \& Evaluation Team, Afghanistan. Bronx: Wildlife Conservation Society

Nabhan GP 2009. Where our food comes from: retracing Nikolay Vavilov's quest to end famine, Island Press, ISBN 9781597263993, Washington D.C

Sher H, Aldosari A, Ali A, de Boer H J 2014. Economic benefits of high value medicinal plants to Pakistani communities: an analysis of current practice and potential. Journal of Ethnobiology and Ethnomedicine 10(1):2 
Soelberg J 2016. Useful Plants of Wakhan and Pamir. Habibullah Haseeb, Kabul, Afghanistan.

Soelberg J, Jager AK 2016. Comparative ethnobotany of the Wakhi agropastoralist and the Kyrgyz nomads of Afghanistan. Journal of Ethnobiology and Ethnomedicine 12(2):24.

Stanikzai MT 2007. Market Report: Liquorice. Tribal Liaison Office, In collaboration with ProFound-Advisors in Development.

Umarov K 1998. The Demographic Boom and its Impact on the Mountain Regions of Tajikistan. In Akiner S, Tideman S and Hay J (eds), Sustainable Development in Central Asia. New York: St. Martin's Press 186-194

United Nations Office for the Coordination of Humanitarian Affairs (OCHA) 2015. Population estimate 2015: http://www.refworld.org/pdfid/55eedf694.pdf

Wafiq A. M. (n.d.). The Role of Medicinal Plants in Afghanistan's Trade. Kabul: Afghan Plants Company, Ministry of Commerce

Walker B, Salt D 2006. Resilience thinking: sustaining ecosystems and people in a changing world. Island Press, London, UK.

World data atlas-Tajikistan: https://knoema.com/atlas/Tajikistan/Gorno-Badakhshan 


\section{Annex}

Annex 1. Plants used for local food and dishes.

\begin{tabular}{|c|c|c|c|c|}
\hline $\begin{array}{l}\text { Local Uses of } \\
\text { Plants }\end{array}$ & Scientific Names & $\begin{array}{l}\text { Local Name of Plants } \\
\text { Tajiki/Dari }\end{array}$ & English Names & $\begin{array}{l}\text { \# of } \\
\text { plants } \\
\text { used }\end{array}$ \\
\hline \multirow[t]{12}{*}{ Herbal tea } & $\begin{array}{l}\text { Ziziphora pamiroalaica Juz } \\
\text { ex Nevski. }\end{array}$ & Jambilak & Blue mint & \multirow[t]{12}{*}{12} \\
\hline & Plantago lanceolata L. & Rishtakashak & plantain & \\
\hline & Mentha asiatica Boriss. & Podina & Mint & \\
\hline & Rosa canina $\mathrm{L}$. & Gulkhor & Dog rose & \\
\hline & Glycyrrhiz glabra L. & Shirinboya, muthq & Licorice root & \\
\hline & Matricaria chamomilla L. & Ramashka & Chamomile & \\
\hline & Helianthus tuberosus L. & Kachalo e khamkhurak & Sunchoke & \\
\hline & Ribes nigrum $\mathrm{L}$. & Qaraqat, Qot e siah & Black currant & \\
\hline & Barberis vulgaris $\mathrm{L}$. & Zargul & Barberry & \\
\hline & Bunium persicum Boiss. & Zeera & Black cumin & \\
\hline & Anethum graveolens L. & Shibit & Dill & \\
\hline & $\begin{array}{l}\text { Salvia sclarea var. } \\
\text { turkestaniana Mottet. }\end{array}$ & Marmarak & Clary Sage & \\
\hline \multirow[t]{10}{*}{ Vegetables/Curries } & Coriandrum sativum L. & Gashniz & Coriander & \multirow[t]{10}{*}{10} \\
\hline & Alium sativum L. & Chosnook & Garlic & \\
\hline & Carthamus tinctorius L. & Musfar & Sawflower & \\
\hline & Cucurbita peopo L. & Kadu & Pumpkin & \\
\hline & Beta vulgaris $\mathrm{L}$. & Lablabu & Beet root & \\
\hline & Solanum melongena L. & Boqlajan/Bodinjan e Siah & Egg plant & \\
\hline & $\begin{array}{l}\text { Fagopyrum esculentum } \\
\text { Moench }\end{array}$ & Grechka & Buckwheat & \\
\hline & Daucus carota $\mathrm{L}$. & Zardak & Carrot & \\
\hline & Linum usitatissimum $\mathrm{L}$. & Zaghir & Flax/lint & \\
\hline & Brassica oleracea L. & Karam & cabbage & \\
\hline \multirow[t]{9}{*}{ Dry fruits/nuts } & Prunus armeniaca L. & Zardalu & Apricot & \multirow[t]{9}{*}{9} \\
\hline & Elaeagnus angustifolia L. & Sinjid, Seezd & Russian olive & \\
\hline & Juglans regia $\mathrm{L}$. & Chormagz & Walnut & \\
\hline & Morus alba L. & Tut & Mulberry & \\
\hline & Prunus malus L. & Seb & Apple & \\
\hline & Prunus avium $\mathrm{L}$. & Alabolu & Wild cherry & \\
\hline & Cerasus avium L. & Gilas & Sweet cherry & \\
\hline & Ficus carica L. & Injeer & Fig & \\
\hline & Prunus amygdalus Batsch. & Badam & Almond & \\
\hline \multirow[t]{10}{*}{ Jam/pickles } & Hippophae rhamnoides L. & Angat, & Seabuckthorn & \multirow[t]{10}{*}{10} \\
\hline & $\begin{array}{l}\text { Rubus crataegifolius } \\
\text { Bunge. }\end{array}$ & Malina & Raspberry & \\
\hline & Prunus malus $\mathrm{L}$. & Seb & Apple & \\
\hline & Prunus armeniaca L. & Zardalo & Apricot & \\
\hline & Prunus persica $\mathrm{L}$. & Shaftalo & peach & \\
\hline & Ferula assafoetida L. & Kamol/Rav & Stinking gum & \\
\hline & Cerasus avium L. & Gilas & Sweet cherry & \\
\hline & Prunus domestica L. & Koksulton Aloocha & Plum & \\
\hline & Pyrus persica Pers. & Nok & Pear & \\
\hline & $\begin{array}{l}\text { Rheum emodeii Wall ex } \\
\text { Mieisn. }\end{array}$ & Chokri & Rhubarb & \\
\hline \multirow[t]{2}{*}{ Juices/compotes } & Punica granatum $L$. & Anar & Pomegranate & \multirow[t]{2}{*}{12} \\
\hline & Cerasus avium $\mathrm{L}$ & Gilas & Sweet Cherry & \\
\hline
\end{tabular}




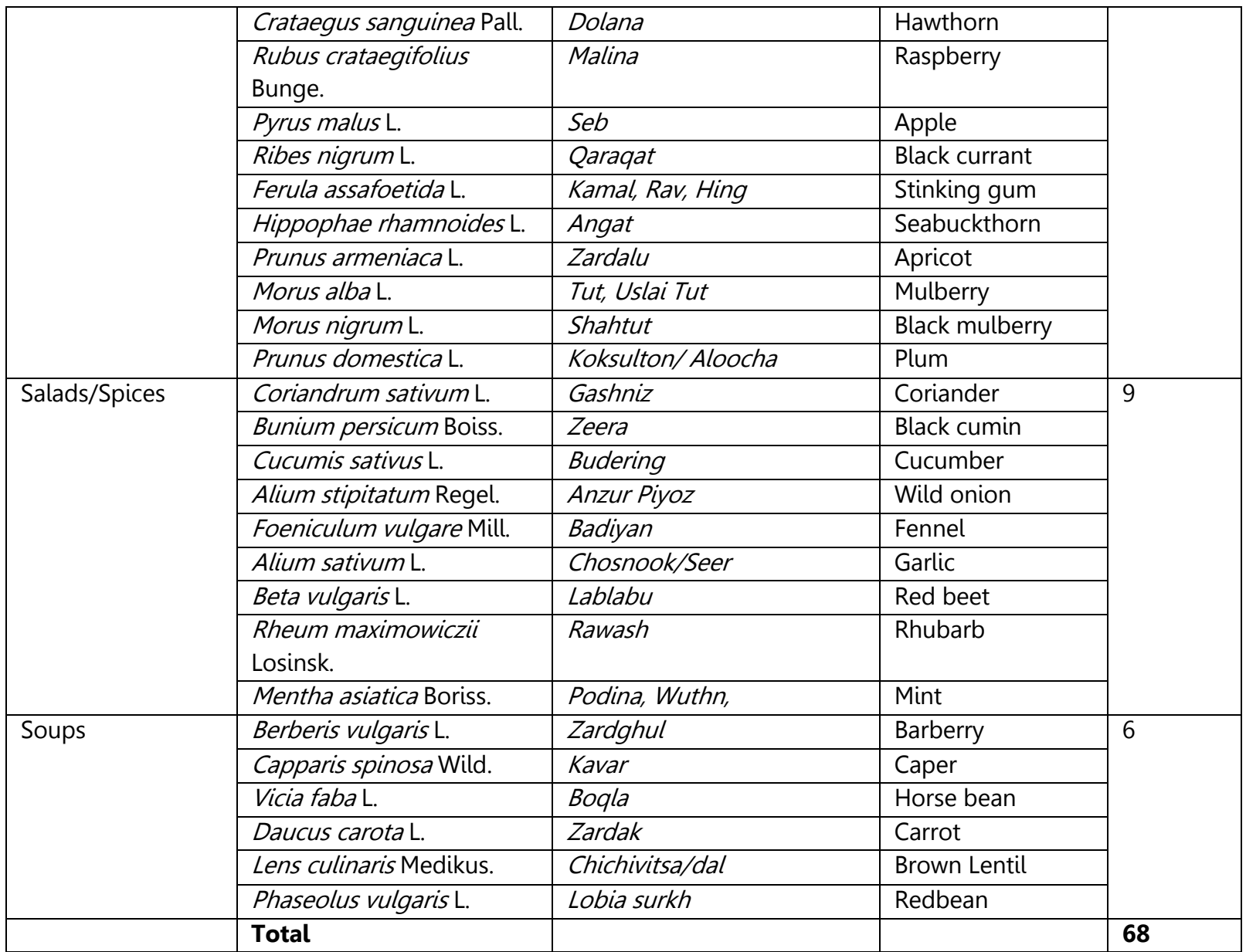

Note: some species of plants are multi-purpose which appear repeatedly in different usage categories of medicinal plants in the table. 
Annex 2: Some of the Medicinal and Aromatic plants of Pamir region

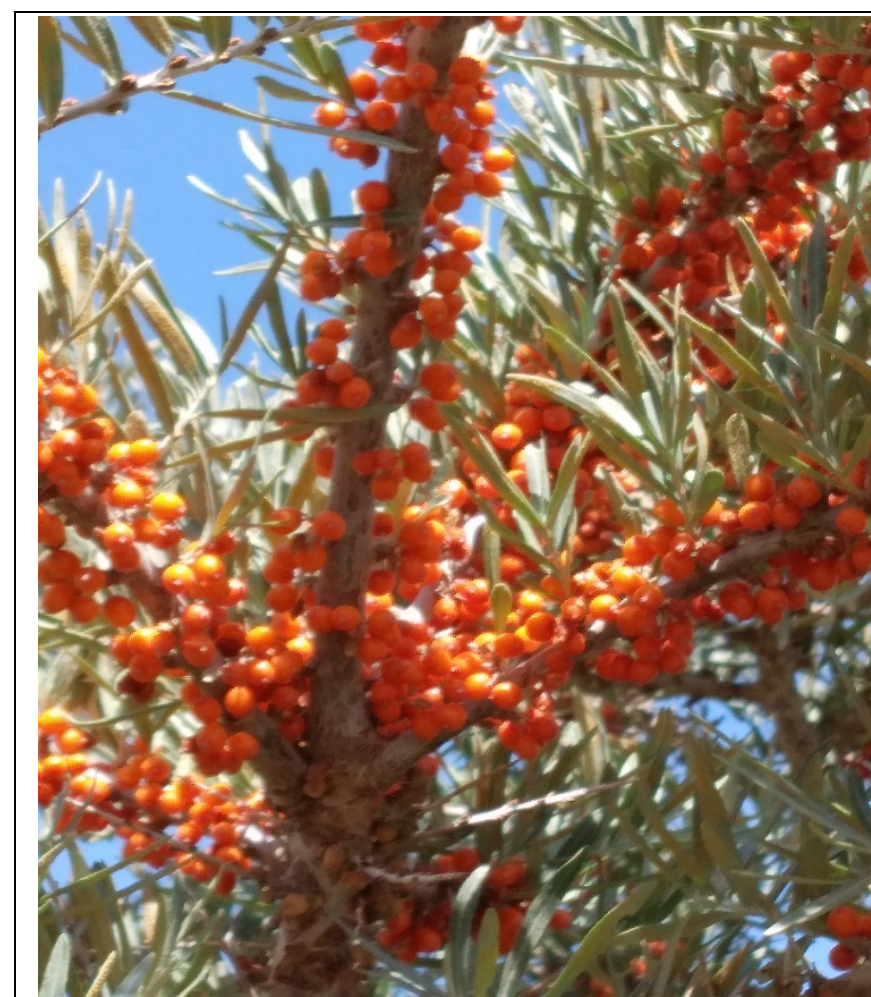

Seabuckthorn (Hippophae rhamnoides L.)

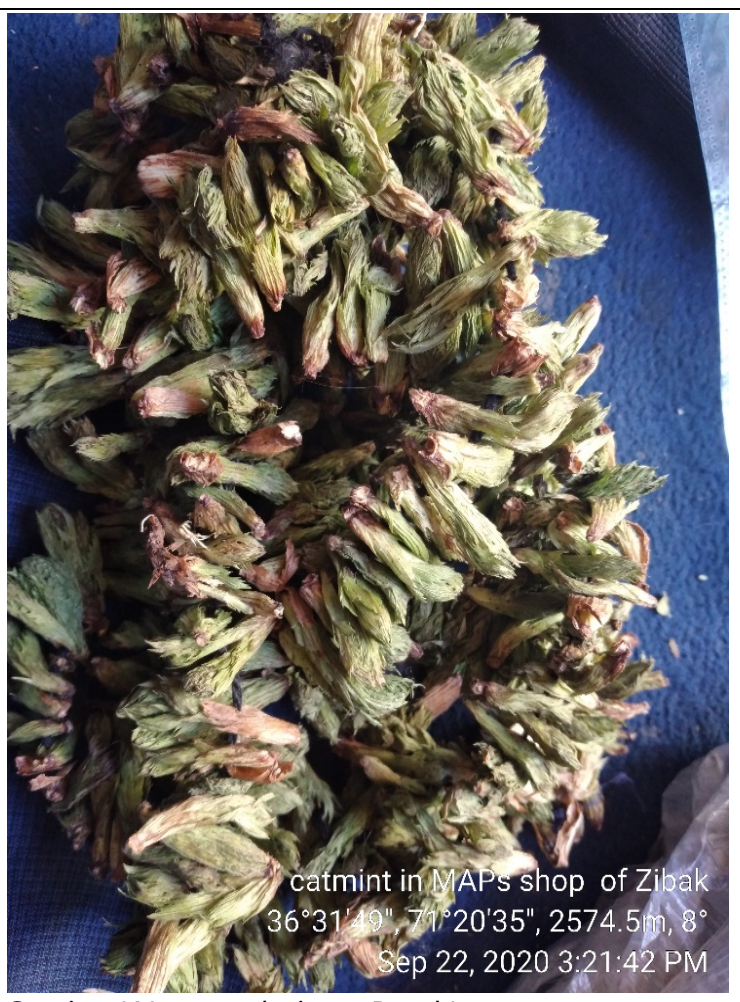

Catnips (Nepeta glutinosa Benth)

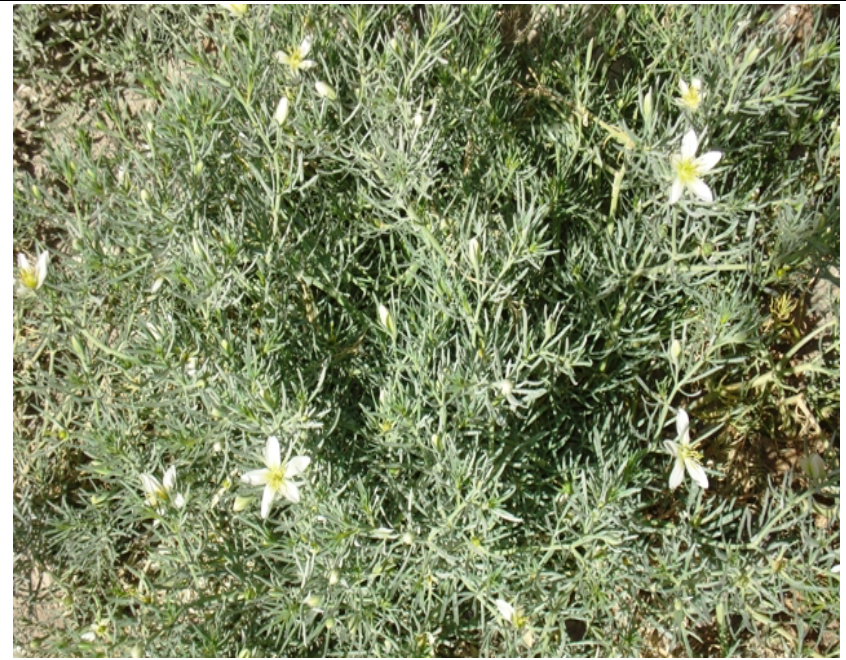

Harmala fruits (Peganum harmala L.) plant

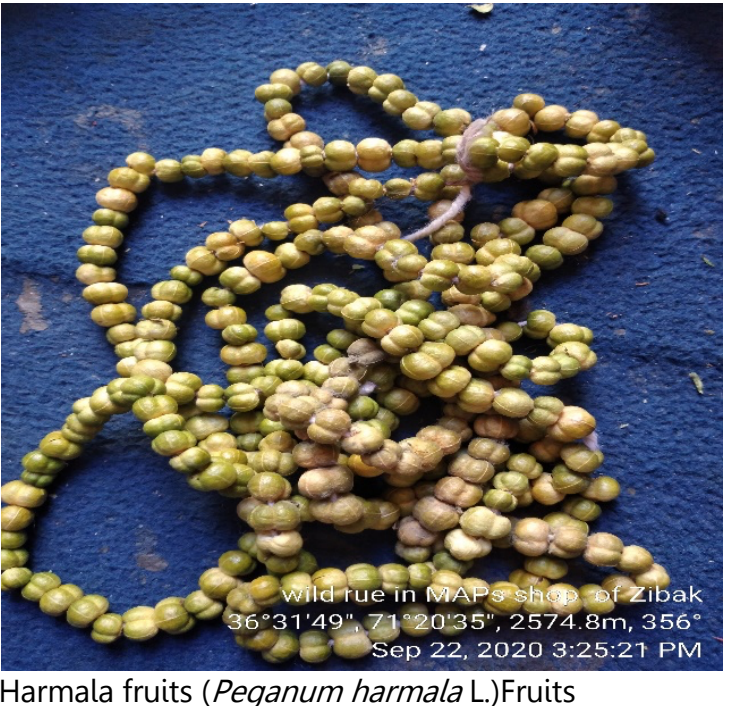



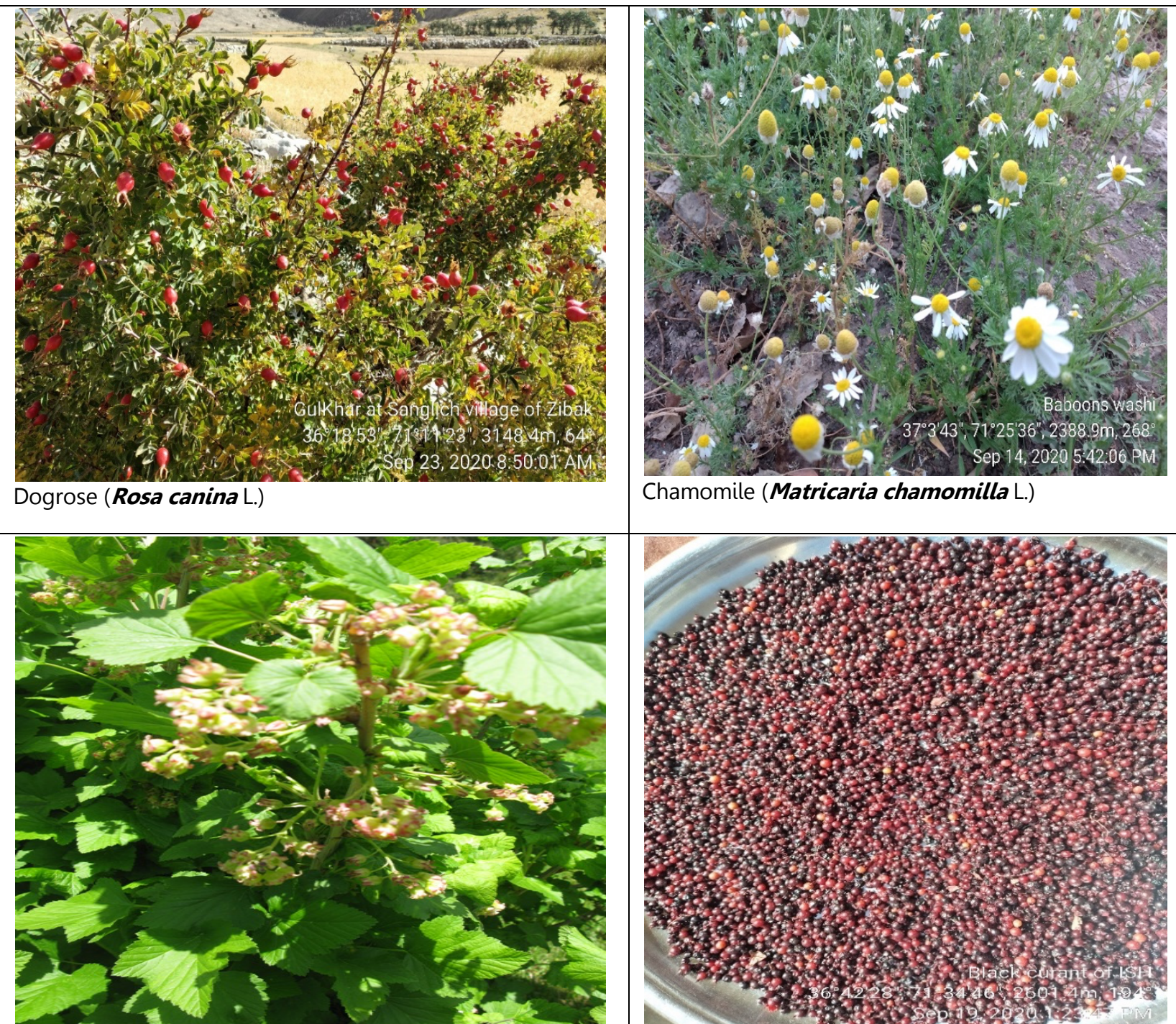

Berries of black currant (Ribes nigrum L.)
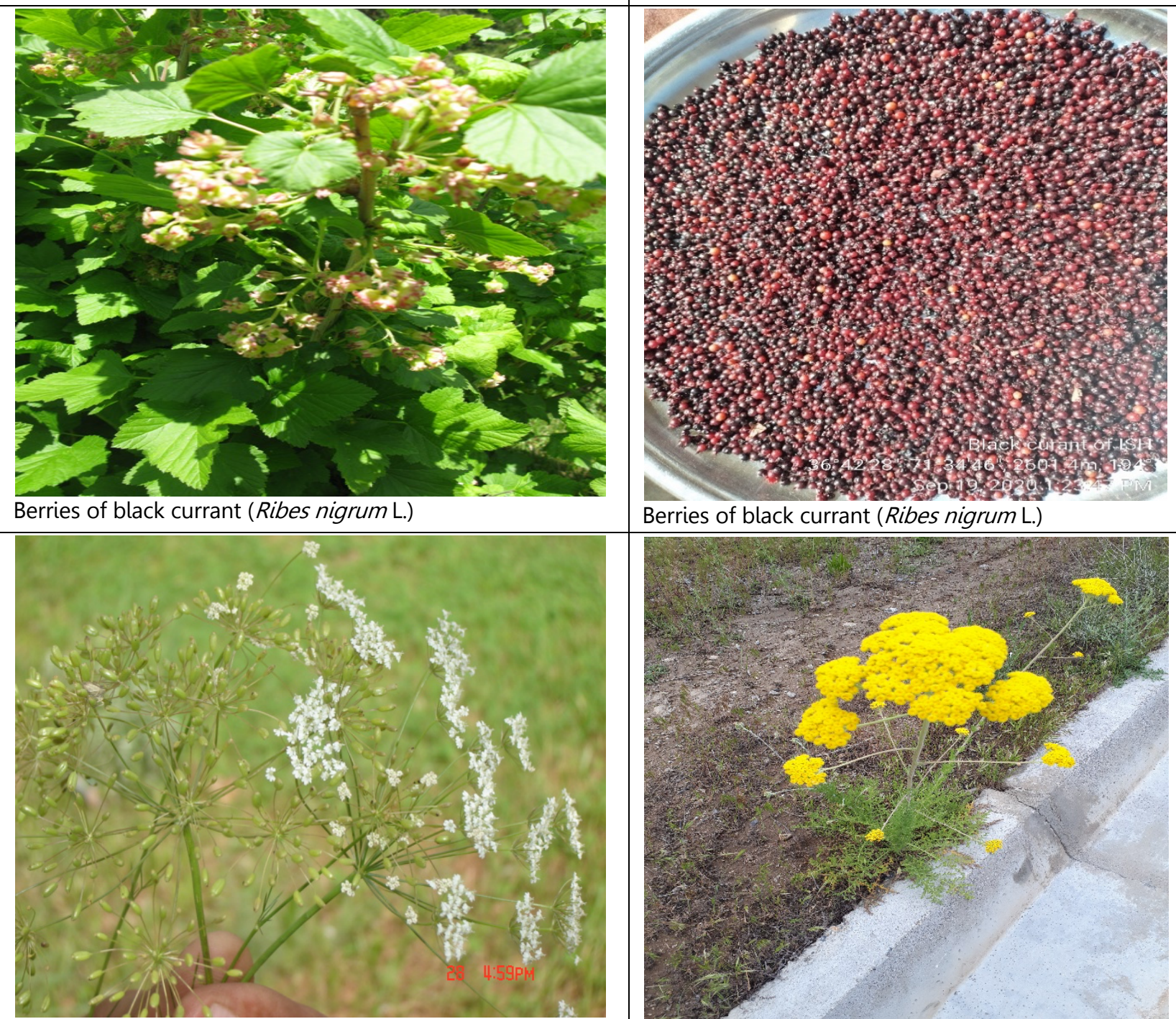

Black cumin (Bunium persicum Boiss.)

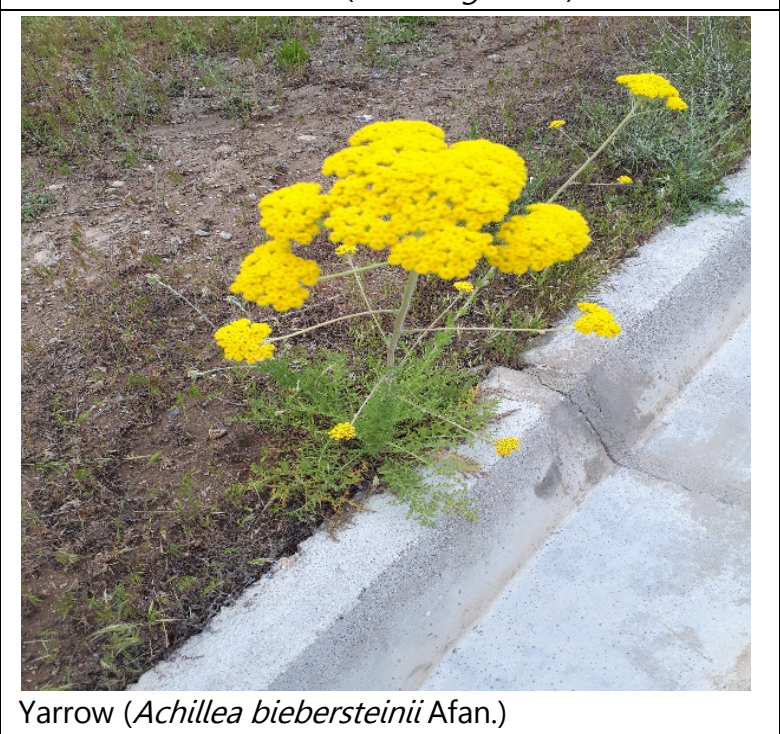




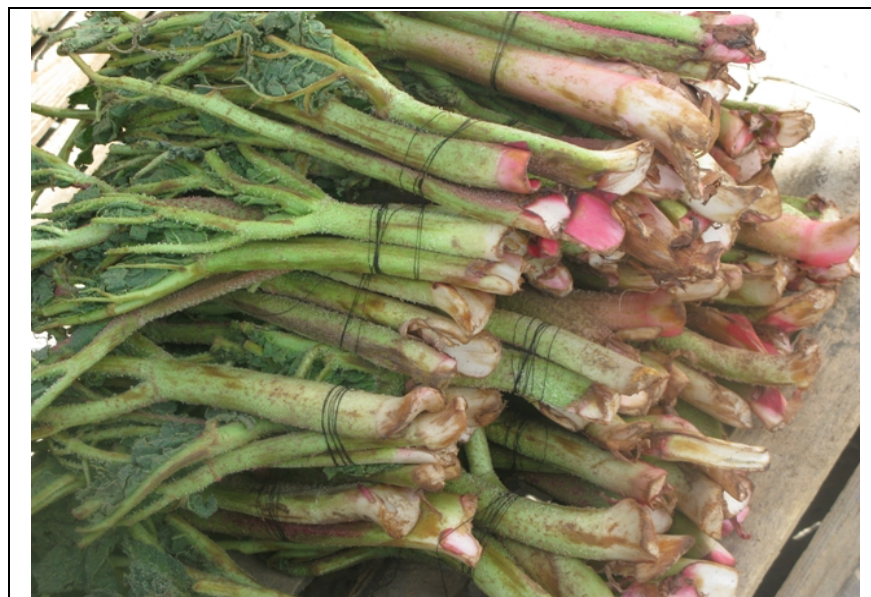

Rhubarb (Rheum emodeii Wall. ex Meissn)
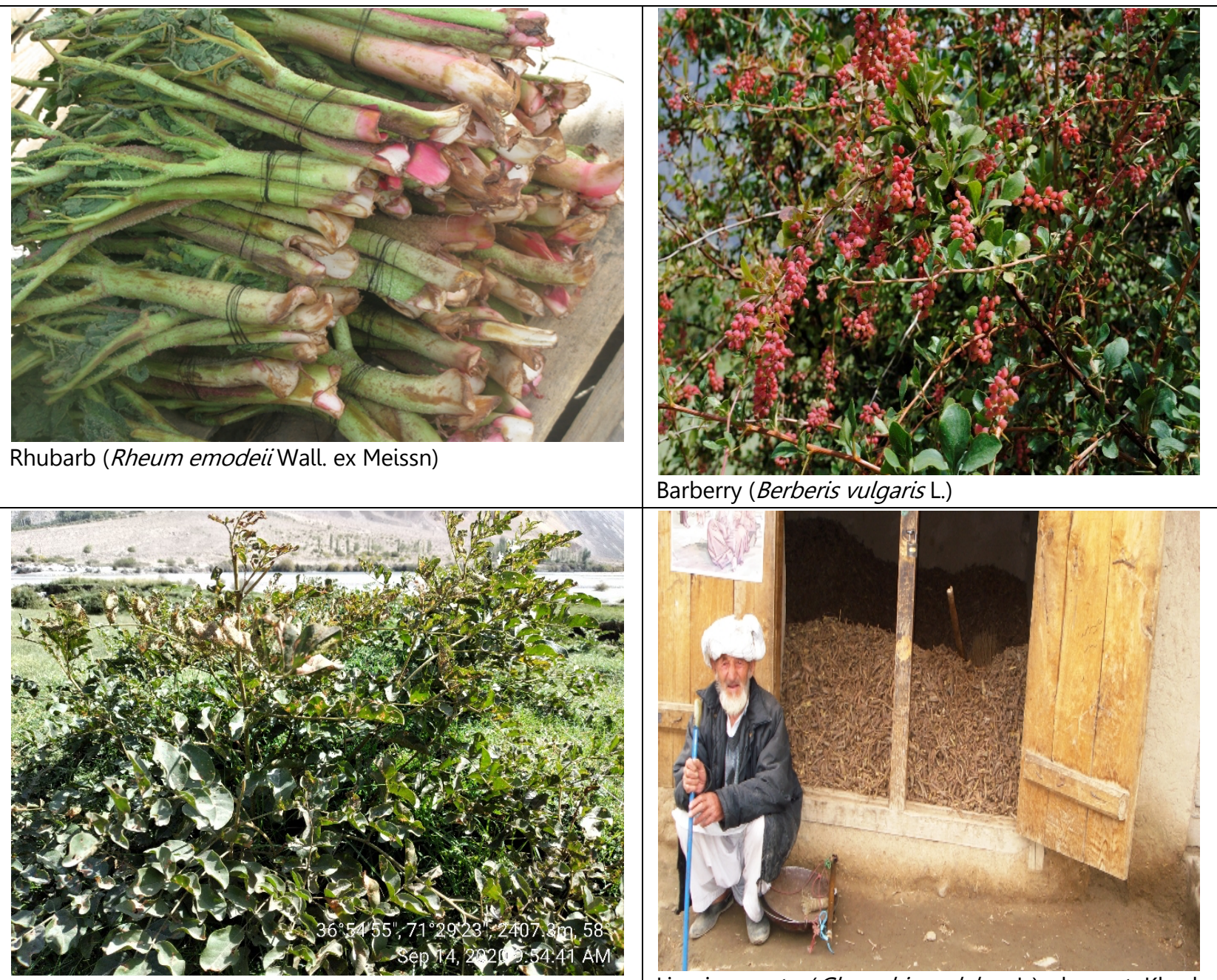

Licorice plant (Glycyrrhiza glabra L.)

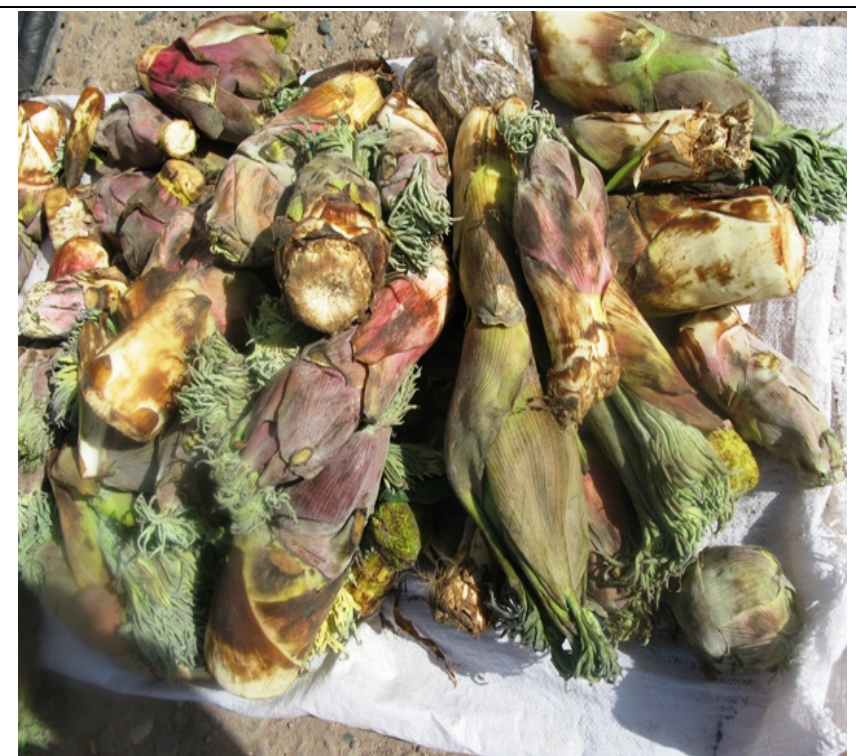

Stinking gum (Ferula assafoetida L.) young shoots

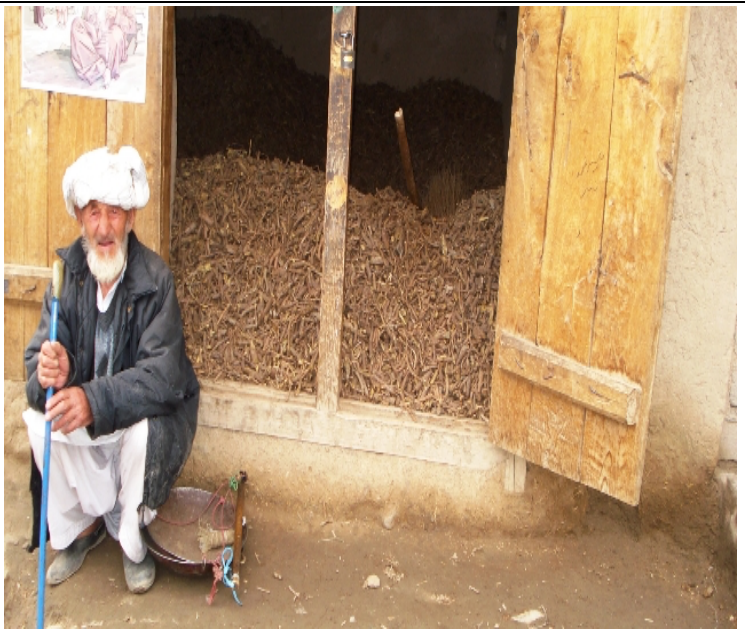

Licorice roots (Glycyrrhiza glabra L.) shop at Khash district Afghan Badakhshan

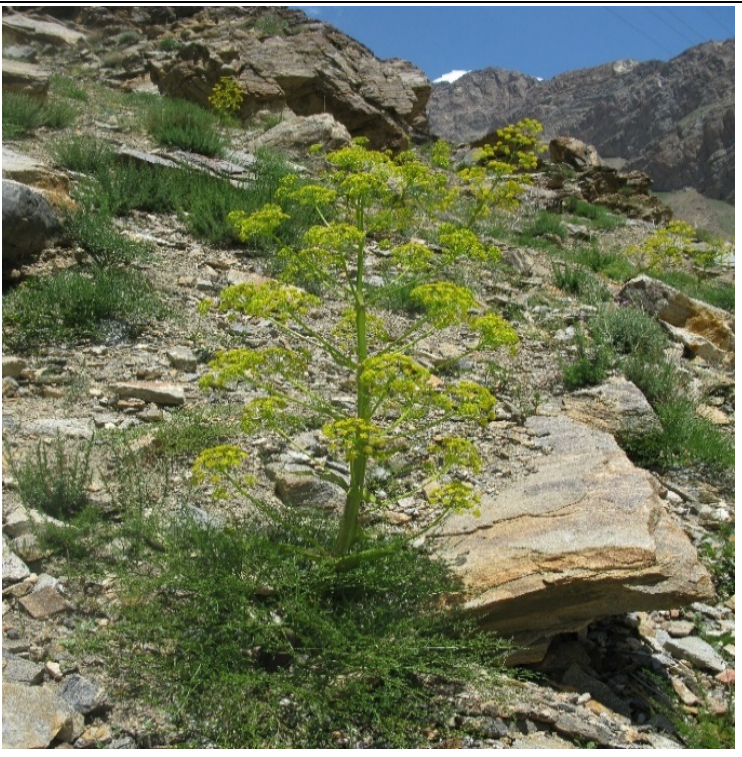

Stinking gum plant (Ferula assafoetida L.) 


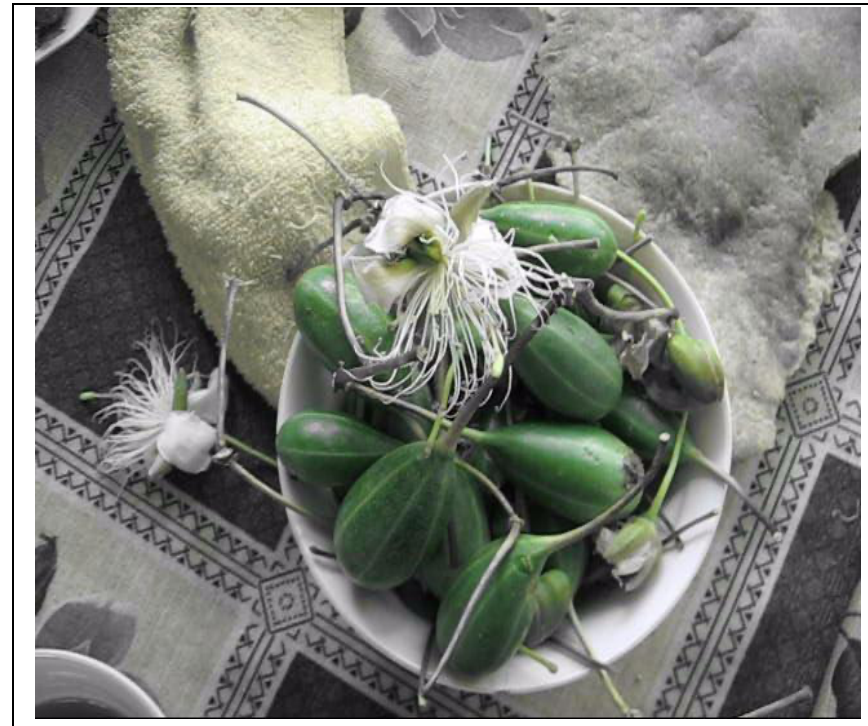

Caper fruits (Capparis spinosa Wild.)

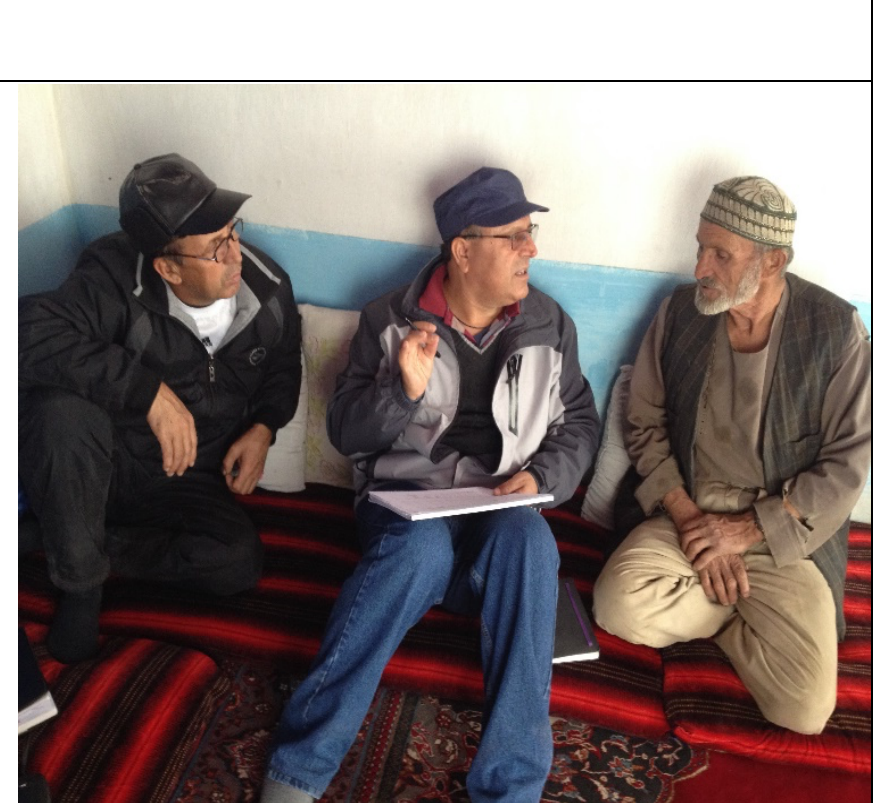

The author interviewing a local herbalist at Ishkashim Afghan Badakhshan, Afghanistan

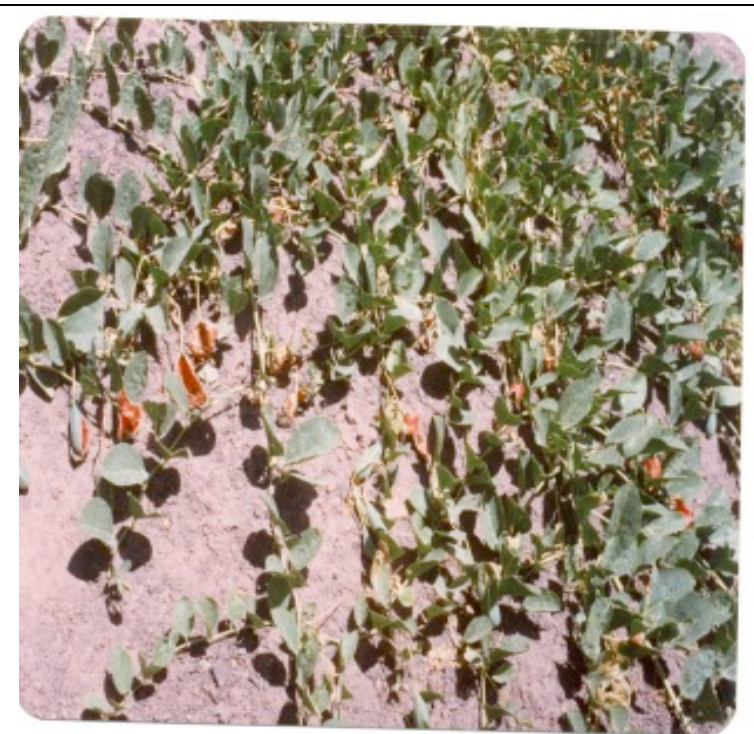

Caper fruits (Capparis spinosa Wild.)

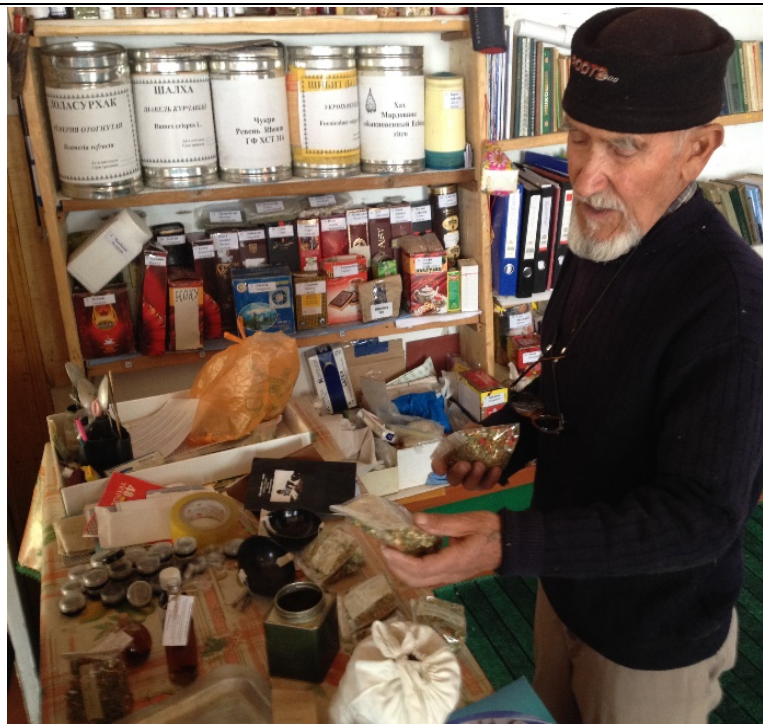

A local herbalist Dr. Shirinbek Ovuj village Tajik Ishkashim, GBAO Tajikistan 